\title{
Felidae from Cooper's Cave, South Africa (Mammalia: Carnivora)
}

Les félidés de la Grotte Cooper, Afrique du Sud (Mammalia: Carnivora)

Running heading: Felidae from Cooper's D

Hannah J. O'Regan ${ }^{1,2 *}$, Christine Steininger ${ }^{2}$,

${ }^{1}$ Department of Archaeology, Humanities Building, University Park, Nottingham, University of Nottingham, NG7 2RD, UK

${ }^{2}$ Evolutionary Studies Institute, University of the Witwatersrand, Private Bag 3, WITS 2050, Johannesburg, South Africa

$*$ author for correspondence

\section{Abstract}

The Cooper's Cave System has produced a diverse fossil assemblage including the remains of Paranthropus robustus Broom, 1938, and early Homo. The majority of the faunal remains come from Cooper's D, which dates to 1.5 - 1.4 Ma. Here we describe 158 craniodental and postcranial felid fossils from Cooper's D, including Dinofelis cf. aronoki. These fossils indicate the presence of four large felid genera at Cooper's D: Dinofelis, Megantereon, Panthera (two species) and Acinonyx, plus two smaller taxa: Caracal and Felis. This assemblage may mark the first appearance of the modern cheetah Acinonyx jubatus (Schreber, 1775) in Africa, as well the first occurrence of the East African species Dinofelis cf. aronoki in southern Africa. This taxon appears intermediate in features between Dinofelis 
barlowi (Broom, 1937) and Dinofelis piveteaui (Ewer, 1955). We compare the Cooper's D felid assemblage with those from other sites in the Cradle of Humankind, Gauteng, and discuss several scenarios for the evolution of the genus Dinofelis in eastern and southern Africa.

Keywords: Cooper's Cave, Felinae, Machairodontinae, Dinofelis cf. aronoki, Megantereon, Panthera, Acinonyx, Caracal, Felis

Mots clés: Grotte de Cooper, Felinae, Machairodontinae, Dinofelis cf. aronoki, Megantereon, Panthera, Acinonyx, Caracal, Felis

\section{Introduction}

Cooper's Cave is one of many hominin-bearing sites located in the UNESCO Sterkfontein, Swartkrans, Kromdraai and Environs World Heritage Site, South Africa. Known as a fossilbearing site since 1939 (Shaw 1939; Shaw 1940) this site is made up of three distinct localities, Cooper's A, B and D each with a unique geomorphology (de Ruiter et al. 2009). The majority of fossils come from the Cooper's D deposit, which has so far produced 183 identifiable individuals, These include carnivores (Kuhn et al., in press; O'Regan et al. 2013; Hartstone-Rose et al. 2007, 2009; Lacruz et al. 2006), primates, including Theropithecus oswaldi (Andrews, 1916) (Folinsbee \& Reisz 2013; DeSilva et al. 2013), hominins (de Ruiter et al. 2009), and unusually for the southern African sites, a number of suids (de Ruiter et al. 2008). Seventeen larger carnivore taxa have been identified (de Ruiter et al. 2009; O'Regan et al. 2013; Kuhn et al., in press), including seven felids representing both extinct and extant taxa. Here we describe the fossil felid material from the Cooper's D deposit (dated to 1.51.4 Ma, de Ruiter et al. (2009)), including Dinofelis cf. aronoki, and additional specimens of 
Megantereon whitei (Broom, 1937). Some of the Dinofelis specimens have previously been discussed in Lacruz et al. (2006) and O'Regan \& Menter (2009), but the identification of further Dinofelis material in the Cooper's D collection, in particular a complete $\mathrm{P}^{4}$, has allowed us to reconsider the designation of the material. In addition to the Dinofelis remains included in Lacruz et al. (2006), a particularly small specimen of Megantereon whitei has also been published from the site (Hartstone-Rose et al. 2007). This specimen is not redescribed here, but is included in the discussions and analyses for completeness.

\section{Materials and methods}

All specimens were identified using the modern and fossil carnivore comparative collections in the Evolutionary Studies Institute, University of the Witwatersrand, Johannesburg, and Ditsong (formerly Transvaal) National Museum of Natural History, Pretoria. Homotherium spp. postcrania were not represented in these collections, so illustrations in Ballesio (1963) were used for comparison. Comparisons with D. aronoki Werdelin \& Lewis, 2001 were through comparison with Werdelin \& Lewis (2001) with additional photographs kindly

provided by L. Werdelin. All measurements were taken by HOR, unless otherwise stated. If a specimen has been previously described, the reference is given in parentheses.

\section{Abbreviations}

Specimen and collection prefixes are as follows: $\mathrm{CD}=$ Cooper's $\mathrm{D}, \mathrm{DN}=$ Drimolen, $\mathrm{KA}=$ Kromdraai $\mathrm{A}, \mathrm{KB}=$ Kromdraai $\mathrm{B}, \mathrm{M}=$ Makapansgat, $\mathrm{AZ}=$ Archaeozoology collection at the Ditsong Museum, BPI = Evolutionary Studies Institute (formerly the Bernard Price Institute). 
Cranial measurement abbreviations: $\mathrm{L}=$ Mesial-distal length of tooth, $\mathrm{B}=$ greatest Buccallingual breath of tooth, Bant $=$ breadth across anterior accessory cusp, $\mathrm{Ba}=$ anterior breadth including protocone, $\mathrm{Bbl}=$ breadth across the carnassial blade, $\mathrm{Lm}=$ length of metastyle, $\mathrm{CB}$ $=$ breadth across the occipital condyles, Lproto $=$ length of protoconid, Lpara $=$ length of paraconid, Depth $\mathrm{A}=$ anterior depth of mandible before to the $\mathrm{P}_{3}$, Depth $\mathrm{P}=$ posterior depth of mandible after the $\mathrm{M}_{1}, \mathrm{BP}_{4}=$ breadth of the mandibular corpus below the $\mathrm{P}_{4}$, Diastema $=$ length of canine- $\mathrm{P}_{3}$ diastema.

Postcranial measurement abbreviations: $\mathrm{TL}=$ total length, $\mathrm{PWM}-\mathrm{L}=$ Proximal mediolateral width, PWA-P, Proximal anterio-posterior width, DWMax = maximum distal mediolateral width, DBMax = maximum distal anterio-posterior breadth, $\mathrm{PWMax}=$ maximum proximal mediolateral width from femoral head to greater trochanter, ND = superior-inferior femoral neck diameter, $\mathrm{HD}=$ superior-inferior femoral head diameter, HeadW = mediolateral width of the head of the astragalus, NeckW = mediolateral width of the neck of the astragalus, DW $=$ distal mediolateral width across the epicondyle.

\section{Systematics}

Order CARNIVORA Bowdich, 1821

Family FELIDAE Fischer, 1817

Subfamily MACHAIRODONTINAE Gill, 1872

Genus Dinofelis Zdansky, 1924

Type Species: Dinofelis cristata (Falconer \& Cautley, 1836)

Dinofelis cf. aronoki 


\section{Synonomy:}

2006 Dinofelis sp. Lacruz et al. p. 94-96.

2009 Dinofelis aff. piveteaui O'Regan \& Menter, p. 331-340.

\section{Material}

Craniodental from Coopers D (all described in Lacruz et al. (2006), with the exception of CD 15696 and CD 19265): CD 16765a+b, right premaxilla fragment with $\mathrm{I}^{1}-\mathrm{I}^{3}$ (Fig. 1G); CD 16769a+b, left $C^{\text {s }}$ (Fig. 1H); CD 15696, left $\mathrm{P}^{3}$ (Fig. 1I-J); CD 7323a-d, right premaxilla with $\mathrm{P}^{3}$ (Fig. 1D-E) and partial $\mathrm{P}^{4}$ (Fig. 1F); CD 19961, complete $\mathrm{P}^{4}$; CD 18836, rear portion of right mandible with $\mathrm{P}_{4}$ and partial $\mathrm{M}_{1}$ (Fig.1K-L); CD 19265, left $\mathrm{M}_{1}$ in mandible fragment (Fig.1M-N). Craniodental from Drimolen, all described and figured in O'Regan \& Menter (2009): DN 1012, a right maxillary fragment with complete $\mathrm{P}^{4}$ and $\mathrm{M}^{1}$, plus partial $\mathrm{C}^{\mathrm{s}}$ and complete $\mathrm{P}^{3}$ alveoli; DN 780, right $\mathrm{P}^{3}$; DN 986, right $\mathrm{P}_{4}$; DN 1020, posterior portion of premolar, probably right $\mathrm{P}^{3}$.

Postcranial material: CD 19953, a right MT 3 (Fig. 2A-B); CD 3233, a left proximal tibia (Fig. 2C-E); CD 7359, a right proximal ulna (Fig 2F-G); CD 038, a left ulna notch fragment. Postcrania from Drimolen described in O'Regan \& Menter (2009): DN 15, left distal ulna; DN 720, left distal radius; DN 86, left distal radius; DN 772, left proximal second metacarpal; DN 2149a-c, associated right tibia, astragalus and calcaneum; DN 2092, left calcaneum; DN 2571, right navicular; DN 12, left second metatarsal; DN 17, left third metatarsal; DN 14, left fourth metatarsal; DN 18, left fifth metatarsal, lacking proximal articulation.

\section{Description}




\section{Craniodental material}

CD 19961 (Fig.1A-C) is a complete $\mathrm{P}^{4}$ that has been glued across the paracone-metastyle border. It is a good fix, with no misalignment, making measurements possible. CD 19961 has a much reduced protocone, and a small ectoparastyle that is in line with the parastyle. The metastyle is not elongated, and has a small rounded area of enamel on its tip. The enamel is rugose. CD 7323a,b,c,d are a series of associated right maxillary specimens. The dental specimens of a complete $\mathrm{P}^{3}$ and two fragments of a $\mathrm{P}^{4}$ were published by Lacruz et al. (2006), but their association with the maxillary fragment (CD 7323d) was not noticed at this time (Fig. 1D-E). Starting with CD 7323a+b (the $\mathrm{P}^{4}$ ) the central portion of the tooth is missing, leaving only the parastyle and metastyle. There is a large ectoparastyle with the cusp tip in line with the parastyle (Fig. 1D), and the metastyle is not elongated (Fig. 1F). In comparison with CD 19961, the ectoparastyle is larger in CD 7323 and although the end of the metastyle is curved, it is not as pronounced as CD 19961. CD 7323c is an isolated right $\mathrm{P}^{3}$ shown refitted into the maxilla in Fig. 1D,E. It is shown in Fig. 3 in Lacruz et al. (2006), but note that their caption is incorrect, as it says that it shows CD 3835, another isolated $\mathrm{P}^{3}$ from the site. The anterior accessory cusps of CD 7323c are unusual, as it has two, both in line with the protocone and curving slightly lingually. They are both smaller than the posterior accessory cusp. A tiny cusplet is also present on the anterior buccal surface, and there is a small cusp present on the tip of the posterior cingulum. The maxillary fragment (CD 7323d) comprises the anterior portion of the $\mathrm{P}^{4}$ alveolus, the full $\mathrm{P}^{3}$ alveolus (into which $\mathrm{CD} 7323 \mathrm{c}$ refits) and the edge of the canine alveolus. The edges of the diastema are worn, but it must have been very small (Fig. 1E). It is not possible to see if a $\mathrm{P}^{2}$ was present. The pinch point of the maxilla is at the posterior root of the $\mathrm{P}^{3}$. 
The following five craniodental specimens (CD 16765a+b, CD 16769a+b, CD 15696, CD 18836, CD 19265) may be associated, based on their proximity to one another when recovered. CD $16765 \mathrm{a}+\mathrm{b}$ is a right premaxilla with the roots of the $\mathrm{I}^{1}, \mathrm{I}^{2}$ and $\mathrm{I}^{3}$ (Fig. 1G). All incisors would have been large; the $\mathrm{I}^{3}$ is in two pieces, but was almost the size of a small leopard canine. The $\mathrm{I}^{1}$ has a small accessory cusp on the medial lingual surface, but the rest of the crown is broken. CD $16769 \mathrm{a}+\mathrm{b}$ is the central portion, including the enamel margin, of a large mediolaterally flattened canine with very strong keels on its labial and lingual surfaces (Fig. 1H). The keels clearly show that it is Dinofelis, and it is from a young animal, as the root was still open. CD 15696 is a left $\mathrm{P}^{3}$, which, like CD 7323c, has an extra anterior accessory cusp, and a buccal cusplet. The anterior cusps are very low, and the cusps are slightly lingually set (Fig. 1I-J). There is a strong posterior cingulum. The similarity of features between CD 7323c and CD 15696 suggest that they may be antimeres. CD 18836 is a lower left mandible broken vertically immediately prior to the $\mathrm{P}_{4}$, and just after the posterior portion of the $\mathrm{M}_{1}$ (Fig. $\left.1 \mathrm{~K}-\mathrm{L}\right)$. The $\mathrm{P}_{4}$ is complete, with large accessory cusps, plus a small cusp on same orientation on the tip of the posterior cingulum. The protocone has two pinched grooves on the buccal surface effectively making the edges of the cusp more bladelike (Fig. $1 \mathrm{~K}$ ). The paraconid of the $\mathrm{M}_{1}$ is damaged, but it can be seen that the tooth is deeply scooped out on the lingual surface (Fig. 1L). There is no talonid on the protoconid. The masseteric fossa is deep and ends just below the posterior of the $\mathrm{M}_{1}$, only the edge of the mental foramen can be seen, and it would have been under the posterior root of $\mathrm{P}_{3}$. The inferior lingual surface of the mandible is ridged. CD 19265 is a very slightly worn left $\mathrm{M}_{1}$ fitting into a buccal fragment of ramus (Fig. 1M). There is a small bladelet on the anterior surface of the paraconid, and a slight curve on the posterior edge of the protoconid, but no evidence of a talonid. The lingual surface of the tooth is deeply scooped (Fig. 1N), in the classic Dinofelis pattern. The very shallow edge of the masseteric fossa is just visible, ending 
just below the back of the protoconid. If this series of specimens are associated, then CD 19265 is the antimere of the broken $\mathrm{M}_{1}$ of CD 18836, however it is slightly larger than this specimen.

\section{Postcranial material}

CD 19953 is a complete right $3^{\text {rd }}$ metatarsal that closely matches DN 17, an MT3 identified as Dinofelis from Drimolen (O'Regan \& Menter, 2009). The only differences between the two specimens are that in CD 19953 the proximal facet curves a little more onto the anterior surface (Fig. 2A) and the epicondyles are larger. It also appears similar to KNM-ER 722T (identified as D. piveteaui (Ewer, 1955) in Werdelin \& Lewis 2001: Fig 20)) except that the anterior is curved in CD 19953, while it appears straight in the Kenyan specimen.

CD 3233 is a left proximal tibia with $1 / 3^{\text {rd }}$ of the shaft (Fig. 2C-E). There is a large protuberance on the lateral surface of the proximal articulation (Fig. 2E), and a deep fossa below the facets on the posterior surface. The fibular facet is large (Fig. 2C). Overall it looks very like DN 2149a (Dinofelis), except that this is from a smaller individual, and the muscle markings on the rear of the shaft are even more pronounced in CD 3233. CD 7359 is a right proximal ulna fragment that is broken across the notch. It is broadened posteriorly and there is a deep fossa proximal to the notch on the medial surface (Fig. 2G), noted by Werdelin \& Lewis (2001) as a characteristic Dinofelis trait. CD 038 is a left ulna notch fragment, which is also posteriorly broad with a fossa on the medial surface. It is from a slightly larger individual than CD 7359, but is otherwise a good match and has been assigned to Dinofelis cf. aronoki.

\section{Comparisons}


Craniodental comparisons are undertaken on a tooth-by-tooth basis, starting with the upper dentition.

Incisors: there is little morphology left on the premaxilla with damaged incisors (CD $16765 \mathrm{a}+\mathrm{b})$, however, it can be seen that there was a small medial accessory cusp on the $\mathrm{I}^{1}$, and that the $\mathrm{I}^{3}$ was very large. Overall, it is slightly smaller than the holotype of $D$. piveteaui (KA 61).

Canines. The upper canine is very mediolaterally flattened, and very slightly $(1 \mathrm{~mm})$ larger than that of KA 61.

Upper P3. CD 7323c and CD 15696 are both shorter with more reduced and slightly more lingually placed anterior accessory cusps than $\mathrm{P}^{3} \mathrm{~s}$ of Dinofelis piveteaui (KA 61 and MT 06/07). In this way they are more similar to DN 780 from Drimolen. It is possible that the two Cooper's specimens are antimeres, but they were found 10 metres apart in the deposit. The lingual bulge finishes at the junction between the protocone and anterior accessory cusp in CD 7323c and CD 15696, while in KA 61 and MT 06/07 it finishes about halfway along the protocone. In both CD 7323c and CD 15696 there is an extra, very low, anterior accessory cusp, so there are two before the protocone in both specimens. There is also an extra anterior accessory cusp visible in Motsetse specimen MT 06/07, but in this case it is a small and very sharp cusp in line with the others. Both CD 7323c and CD 15696 have tiny extra cusplets on the buccal surface, a feature that is also seen in Dinofelis piveteaui from Kromdraai (KA61) and Motsetse (MT 06/07), but not in D. barlowi (Broom, 1937) (BF 55-23). The anterior accessory cusps of KNM ER 2612 (D. petteri Werdelin \& Lewis 2001) and KNM ER 3880 (D. aronoki) are also small and lingually placed, but they do not have any additional cusps or cusplets (J. Kibii, pers comm.). The posterior cingulum is present but small with a cusp on the tip in CD 7323c and CD 15696. The posterior cingulum with small cusp is also present in 
D. petteri specimens (KNM-ER 2612 and KNM-ZP 444) and the D. aronoki type specimen (KNM-ER 3880) but is almost absent in MT 06/07 (D. piveteaui).

Upper P4. The two Cooper's D upper $\mathrm{P}^{4}$ s differ slightly. CD 19961 has a tiny protocone and all the cusps are aligned in a row like $D$. piveteaui, yet the metastyle is not elongated. The ectoparastyle is present and distinct, but not as clear as that of CD 7323a+b which is much larger. The type specimen of $D$. aronoki (ER-3880) lacks an ectoparastyle, while in $D$. petteri it appears variable (ER 2612 lacks an ectoparastyle, and KNM-ZP 444 has a small, centrally placed cusp in line with the parastyle (J. Kibii, pers. comm.)). The lack of an ectoparastyle in D. aronoki marks a difference between this species and the southern African specimens and D. piveteaui, but it is a variable trait. O'Regan (2002) found that in a sample of 30 modern jaguars (Panthera onca), 25 had an ectoparastyle but it was only present in one out of 20 leopards. The metastyle is not elongated in CD 7323a+b, DN 1012 nor in D. aronoki (ER 3880) or D. petteri (ZP 444). The protocone is missing from CD $7323 \mathrm{a}+\mathrm{b}$, is small in CD 19961, and slightly larger in DN 1012. Unfortunately the protocone is broken in D. aronoki (KNM-ER 3880), and both D. petteri specimens (ER 2612, ZP 444) have a larger protocone than CD 19961. Turner (1987a) highlights the double ogival curve of the anterior edge of the paracone in Dinofelis barlowi and its absence in D. piveteaui. This feature is not present in CD 19961, DN 1012 or D. aronoki. The comparative metrics $\mathrm{P}^{4} \mathrm{~s}$ of African Dinofelis $\mathrm{P}^{4} \mathrm{~s}$ are shown in Figures 3 and 4. Fig. 3 demonstrates that metrically the Cooper's D tooth is narrower across the protocone than all other recorded specimens, while Fig. 4 shows that the metastyle is not elongated like that of $D$. piveteaui, falling instead with $D$. barlowi and $D$. aronoki. 
Maxilla. The postcanine diastema is short in both CD 7323d and DN 1012, making them most similar to D. piveteaui and D. petteri. Both Cooper's D and Drimolen specimens are slightly damaged, but their diastemas would have been no more than $\sim 5 \mathrm{~mm}$, while that of Dinofelis aronoki (KNM-ER 3880) appears to have been at least $1 \mathrm{~cm}$ (based on photographs although the specimen is distorted) and D. barlowi (BF 55-22) approximately $11 \mathrm{~mm}$ (O'Regan \& Menter 2009). The maxilla of CD 7323d is pinched at the posterior root of the $\mathrm{P}^{3}$, while in D. aronoki (KNM-ER 3880) it appears to be pinched prior to the $\mathrm{P}^{3}$ (although it is heavily reconstructed), and in DN 1012 and KA 61 it is pinched at the anterior root of the $\mathrm{P}^{3}$ (O’Regan \& Menter 2009).

Lower $\mathrm{P}_{4}$. There is one $\mathrm{P}_{4}$ from Cooper's $\mathrm{D}$, in the partial mandible CD 18836. In comparison with KA 62 and MT 03 (both Dinofelis piveteaui), the Cooper's D specimen is intermediate in size between the two. KA 62 is more robust and the cusps are clearer and larger, while in MT 03 they are lower and more rounded. They also lean slightly lingually, while those of CD 18836 are more upright, but the protocone and anterior accessory cusp are slightly backwards sloping. In KA 62 the anterior cusp is almost directly at the edge of the tooth, while in CD 18836 it is set very slightly back. The anterior portion of CD 18836 is much narrower than the posterior portion, this is also seen in MT 03 (D. piveteaui), KNM-ER 3880 and ER 1549 (both $D$. aronoki), but not in the other specimens available for study (Dinofelis barlowi (BF 55-23), D. piveteaui (KA 62) and D. darti (Toerien, 1955) (M 607)). The $\mathrm{P}_{4}$ of CD 18836 has a very strong posterior cingulum, which is also seen in KA 62 and MT 03, and ER 1549 (a mandible identified as D. aronoki (Werdelin \& Lewis 2001)), but not in the other specimens.

Lower M1. Two lower $\mathrm{M}_{1} \mathrm{~s}$ have been recovered from Cooper's D, both contained in ramus fragments - CD 19265 and CD 18836. These $\mathrm{M}_{1}$ s are deeply scooped out, making the cusps 
appear concave on the lingual surface. They closely match the $D$. piveteaui lower $\mathrm{M}_{1}$ in mandible KA 63 in size and morphology, the only slight difference is that the talonid bulge is slightly more obvious in KA 63 than in CD 19265, and no talonid is visible in CD 18836. We have observed that the protoconid is considerably longer than the paraconid in the Cooper's D specimens, but there are few comparable specimens complete enough to metrically test this feature against other taxa. This elongation of the protoconid is also seen in ER 1549 (D. aronoki), but not in D. petteri (KNM-KP 30397) or ER 3880 (D. aronoki).

Ramus morphology. In CD 18836 the masseteric fossa is deep and ends just below the posterior of the $\mathrm{M}_{1}$. The broken edge of a mental foramen can be seen, and would have been under the posterior root of $\mathrm{P}_{3}$. The lingual inferior surface is ridged, a feature that is not seen in SK 335 (identified as Dinofelis sp.), or KNM-KP 30397 (D. petteri), but is present in ER 3880, and may have been present in ER 1549, but this area is damaged.

Discussion of Dinofelis remains.

Overall, the material from Cooper's D is similar to both Dinofelis piveteaui, and Dinofelis aronoki. The specimens from Cooper's D and Drimolen have a clear ectoparastyle on the $\mathrm{P}^{4}$, and an elongated protoconid on the $\mathrm{M}_{1}$. Both these features differentiate this material from the type of D. aronoki (ER 3880). On the other hand the material differs from D. piveteaui as the metastyle of the $\mathrm{P}^{4}$ is not elongated, although the protocone is greatly reduced. Overall, the similarities of the Cooper's D and Dimolen specimens are to D. aronoki rather than $D$. piveteaui and have here been referred to that species. However, we note that the mandible ER 1549 from the Upper Burgi member, Koobi Fora, referred to D. aronoki by Werdelin \& Lewis (2001), appears to be more similar to the Cooper's material than it does to the type specimen of $D$. aronoki (ER 3880). The possibility that the variability seen in the Upper Burgi material might represent two species was noted by Werdelin and Lewis (2001: 234), 
but the material was not sufficient to make a distinction at the time. While we cannot be certain of intra-specific variability within Dinofelis species, owing to an overall paucity of material at any one site, these differences in. We are mindful that the differences in the carnassials between the type material of $D$. aronoki and the material referred here to $D$. cf. aronoki, may be significant, and it is possible that the new South African material represents a new species which cannot be diagnosed on the available material. We therefore refer it to D. cf. aronoki, pending the discovery of further material, when further work may shed light on the evolution of these late machairodont species in Africa.

Genus Dinofelis Zdansky, 1924

cf. Dinofelis aronoki

Cranial: CD 1555, right anterior mandible fragment from symphysis to $\mathrm{P}_{3}$ alveoli. CD 15660 , two refitting $\mathrm{I}^{2}$ crown fragments.

Postcranial: CD 670, a damaged right MT4; CD 650, a right MT 4 shaft fragment; CD 3284, a $1^{\text {st }}$ phalanx; CD 1195, a dew claw $1^{\text {st }}$ phalanx; CD 979, a $3^{\text {rd }}$ phalange; CD 3881, a left distal tibia; CD 5674, a right unciform; CD 654, a right femoral head; CD 3712 + CD 5972, two refitting pieces of a right distal radius.

CD 1555 is an edentulous right mandible fragment, with the lower portion of the symphysis present, retaining the alveoli of the $\mathrm{I}_{3}$ and $\mathrm{C}_{\mathrm{i}}$, plus the complete diastema and both alveoli for the $\mathrm{P}_{3}$. There is a small symphyseal bulge, but it is clearly not a flange with a near vertical ramus, as seen in Megantereon whitei from the same site (CD 5997, Fig. 5B). There is a 
single, very large, mental foramen below the anterior root of the $\mathrm{P}_{3}$. The inferior border of the mandible is straight. There is a distinct dip on the lingual surface of the ramus that is also seen in CD 18836 (Dinofelis cf. aronoki) and M607 (D. darti from Makapansgat) and is much less pronounced in leopard. CD 15660 is a fragmentary $\mathrm{I}^{2}$ in two pieces; it has a large central cusp and a pronounced accessory cusp, with a tiny worn extra cusplet between the two. It matches well with KA 61 (Dinofelis piveteaui from Kromdraai A), although a slight ridge leads from the accessory cusp to the lingual surface, which is not as pronounced as that of KA 61 .

\section{Postcrania:}

CD 3712 and CD 5972 are refitting right distal radius fragments. The bone is intermediate in size between lion and leopard, with a narrower articulation (anterior-posterior) than is seen in leopard. The ulnar facet is very large and placed slightly off-centre with strong ridges above it. It is similar to, but smaller, than DN 86 a Dinofelis specimen from Drimolen. However, the distal facet is more rectangular in the Coopers specimen and the ridge along the fusion line is not so distinct. It is therefore assigned to cf. Dinofelis. CD 5674 is a complete right unciform. It is not from a pantherine cat. It matches an unnumbered Dinofelis specimen from Makapansgat in size and in the length of the distal facet, although the anterior surface is a slightly different shape. It also matches KNM-ER 722I, Dinofelis piveteaui, illustrated in Werdelin \& Lewis (2001, fig. 19). It is therefore assigned to Dinofelis. CD 1195 is a complete first dew claw phalanx, which appears to have been slightly gnawed. There are two clear and equally-sized lobes to the proximal articulation and has a distinct protuberance on the dorsal surface. In lion the proximal articulation is not so defined, and in Homotherium (as shown by Ballesio 1963) one facet is smaller than the other. It is most like an unnumbered Dinofelis sp. specimen from Makapansgat, and it has therefore been referred to that genus. 
CD 654 is a right proximal femoral head broken across the neck. The articulation continues onto the neck a little, a feature that is not seen in the extant cats, but is seen in Makapansgat Dinofelis specimen 16190M. The articulation also extends onto the neck in Megantereon whitei. However, the head is not as rounded in Megantereon KB 5333L as it is in CD 654, and it has therefore been assigned to Dinofelis. CD 3881 is a distal tibia, broken just above the articulation. The distal articulation is broader than that of the leopard, and the shaft of Megantereon is more triangular rather than squared as in this specimen. It is a good match for DN 2149a, Dinofelis from Drimolen, but it is from a smaller animal. CD 670 and CD 650 are Dinofelis-sized right $4^{\text {th }}$ metatarsals. CD 670 is almost complete, but the proximal articulation is large missing. CD 650 is a shaft fragment with the beginnings of the proximal articulation. Both are much more robust than leopard, and have similarities to DN 14 from Drimolen, however there are some slight differences in the position of the remaining facets, so they have been assigned to cf. Dinofelis aronoki. CD 3284 is a complete first phalanx, which is a good match for KB 6037 (Dinofelis sp.). It is slightly shorter than this specimen, but has a slightly flattened shaft and the same dip on the dorsal surface between the condyles. CD 979 is a large felid third phalanx. It is too small for Homotherium (if the unnumbered Makapansgat specimen is Homotherium, as suggested by Werdelin \& Lewis (2001, p. 190)), and is a good size match for an unnumbered $D$. darti paw that is also from Makapansgat.

Genus Megantereon Croizet \& Jobert, 1828

Megantereon whitei (Broom, 1937)

Material: Craniodental: CD 5963, right posterior mandible fragment with $\mathrm{M}_{1}$ roots (Fig. 5A); CD 5997, left mandible from symphysis to $\mathrm{M}_{1}$ (Fig. 5B, and see Hartstone-Rose et al. 2007); 
CD 10452, damaged right $\mathrm{M}_{1}$ (Fig. 5C-D); Postcranial: CD 3221, left proximal tibial epiphysis; CD 7336, left navicular; CD 5978, right navicular.

\section{Description and taxonomic assignment}

The three craniodental specimens are clearly attributable to Megantereon (Fig. 5A-D). The most complete, CD 5997, is shown in Fig. 5B and fully described by Hartstone-Rose et al. (2007). The other two specimens are also from the lower jaw. CD 5963 is a posterior fragment of mandible, broken horizontally above the condyle and also anterior to the $\mathrm{M}_{1}$ alveolus (Fig. 5A). The masseteric fossa is shallow and extends to the posterior root of the $\mathrm{M}_{1}$, but the most notable feature is the very small distance $(22 \mathrm{~mm})$ between the angle of the ramus and the condylar process. The coronoid process must have been correspondingly small, and this indicates that the specimen can only have belonged to a very small machiarodont. CD 5963 is of similar size to CD 5997, although the carnassial in CD 5963 may have been slightly larger. CD 10452 is an unworn $\mathrm{M}_{1}$ that is broken across the protoconid (Fig. 5C-D). The paraconid is small (length: $8.7 \mathrm{~mm}$ ) with a relatively larger protoconid. It is much smaller than KA64, and is most similar to the heavily damaged type specimen of Megantereon whitei (TM 856) from Schurveberg (Broom 1937, Turner, 1987b. In contrast, both the $\mathrm{P}_{4}$ and $\mathrm{M}_{1}$ of CD 5997 are smaller than those of TM 856. As discussed by HartstoneRose et al. (2007) the previously known Megantereon whitei material from Coopers D is very small, and these specimens fit within that hypodigm. They most closely fit with the morphology of the type specimen of $M$. whitei, and there is growing consensus that $M$. whitei is the only Pleistocene species of the genus Megantereon in Africa (Palmqvist et al. 2007; Werdelin \& Peigne 2010). Therefore the Cooper's D specimens are assigned to this species. Three postcranial specimens have also been assigned to $M$. whitei. An isolated proximal epiphysis from a left tibia with some damage to the ventral edge (CD 3221) is an excellent 
match for KB 5333M, a partial skeleton of Megantereon whitei published by Vrba (1981). The two naviculae (CD 7336 and CD 5978) may be antimeres and are very similar to the illustrations of M. cultridens (Cuvier, 1824) from Senéze (Christiansen \& Adolfssen 2007) and KB 6018 (Megantereon whitei). In comparison with DN 2571 (here referred to D. $c f$. aronoki) the two Cooper's D naviculae are smaller, not so thick and have less clearly defined facets.

\section{cf. Megantereon whitei}

Material: Craniodental: CD 10497, left $\mathrm{I}^{3}$ (Fig. 5E). Postcranial: CD 1415, right tibia; CD 1156 , right $2^{\text {nd }}$ Metatarsal, CD 3268, left $2^{\text {nd }}$ Metatarsal.

\section{Description and taxonomic assignment}

CD 10497 is a complete $\mathrm{I}^{3}$ that closely matches KA 64, a crushed Megantereon cranium from Kromdraai A. However, CD 10497 has two cusps on the medial surface (Fig. 5E) rather than the one seen in KA 64. It is most likely that this is simply an aberrant individual, but for this reason the specimen is assigned cf. Megantereon whitei. CD 1415 is the damaged distal portion of a tibia, with the epiphyseal fusion line still visible. The shaft is rounded in crosssection, like that of KB 5333T (Megantereon whitei), while those of Dinofelis (DN 2149a and $16201 \mathrm{M})$ are much more triangular. The distal articulation is broad and there are two sections to the fibula facet, like that of KB 5333T. Overall it is most like KB 5333T and is therefore assigned to cf. Megantereon. CD 1156 is a right $2^{\text {nd }}$ metatarsal, lacking the distal condyle and with some damage to the proximal articulation. The shaft is less rounded than that of a modern leopard (AZ 1063), but is similar to that of KB 5339A, and the position and shape of the MT3 facets match those of the Megantereon specimen. However, it is substantially smaller than KB 5339A, hence its referral as cf. Megantereon. CD 3268 is a proximal left $2^{\text {nd }}$ 
metatarsal and half of the shaft. The proximal articulation is extended dorsally, behind the main facet. This extension is also seen in Megantereon (KB 5339A) but not in leopard or puma. It is therefore assigned to cf. Megantereon.

\section{Machairodontinae indet.}

Cranial: CD 3835, right $\mathrm{P}^{3}$ (Fig. 5F-G); CD 1514, left posterior mandible fragment with $\mathrm{M}_{1}$ roots in alveoli (Figured in Lacruz et al. 2006: Fig 5).

Postcranial: CD 1368, right unciform; CD 7708, left unciform; CD 717, left proximal $2^{\text {nd }}$ Metacarpal; CD 1500, right proximal $2^{\text {nd }}$ Metacarpal; CD 1524 right proximal $3^{\text {rd }}$ Metacarpal; CD 5703, left proximal $3^{\text {rd }}$ Metacarpal; CD 7354, right proximal $4^{\text {th }}$ Metacarpal; CD 3271, complete right $5^{\text {th }}$ Metacarpal; CD 682, left proximal $5^{\text {th }}$ metacarpal; CD 1501, $1^{\text {st }}$ phalanx fragment.

Description and taxonomic assignment

CD 3835 (Fig. 5F-G) is a $\mathrm{P}^{3}$, published by Lacruz et al. (2006) as Dinofelis sp., but note that this is not the tooth shown in their figure 3 (the specimen numbers were transposed and their figure 3 shows CD 7323c, a clear Dinofelis tooth). CD 3835 is highly likely to be from a machairodont, but the morphology differs from the other D. cf. aronoki specimens and the possibility that it is Megantereon cannot be excluded. CD 1514 is an edentulous mandible fragment, broken at the $\mathrm{P}_{4}$ and lacking the mandibular angle and top portion of the ascending ramus. The $\mathrm{M}_{1}$ alveolus is very large, longer than $\mathrm{CD} 18836$ (a complete $\mathrm{M}_{1}$ ), yet the ramus itself is very shallow. The edges of the alveolus are very sharp, perhaps suggesting some sort of infection, which may have increased the alveolar margins slightly. Alternatively, it may just be remodelling following the eruption of the tooth. The inferior margin of the ramus is 
curved, and there is no sign of the lingual ridge that is present in CD 18836 and M 607 (D. darti from Makapansgat). It is apparent that the $\mathrm{M}_{1}$ roots were not complete, indicating that this was a young animal at death. This specimen was published as Dinofelis sp. by Lacruz et al. (2006), but the shallow mandible in combination with the size of the carnassial makes this assignment doubtful. It is not Megantereon, as it is too large, and the inferior margin of the ramus is curved rather than straight. The alveolus would fit the Motsetse D. piveteaui carnassial, but is much longer than any other D. piveteaui or D. barlowi specimen. However, in KA 63, the inferior border of the ramus is straighter than CD 1514, and the shape of the masseteric fossa is very different. It is clearly from a young animal, which makes assignment to species difficult and the possibility that it is a young Homotherium cannot be excluded. It has therefore been referred to Machairodontinae indet.

Ten postcranial specimens are assigned to Machairodontinae indet. Unciforms CD 1368 and CD 7708 appear to be antimeres and are smaller than a modern leopard, but are larger and different to caracal. An unnumbered Dinofelis unciform from Makapansgat is much squarer and slightly more twisted than the Cooper's specimens. They are very similar to the inner view of the Senéze M. cultridens specimen figured in Christiansen \& Adolfssen (2007: Fig. 19M), but differ from the outer view of the same bone (their Fig. 19N), for this reason they are assigned as Machairodontinae indet. Four right metacarpals CD 1500, CD 1524, CD 7354 and CD 3271 refit to form the proximal portion of a front foot, referred to here as 'the paw'. All four specimens in the paw are slightly smaller and have proximal articulations that are narrower medio-laterally than is seen in the modern leopard, puma and cheetah. They are much more gracile than specimens assigned to Dinofelis and appear similar to the Senéze Megantereon cultridens material illustrated in Christiansen \& Adolfssen (2007). They are 
also slightly more gracile than KB 5333U, the only metacarpal assigned to Megantereon that is available for comparison. As the craniodental Megantereon material from Coopers shows that it is a small cat, perhaps gracility in the postcrania is also to be expected, but in the absence of better comparative material they are here assigned to Machairodontinae indet., with the recognition that they may be Megantereon. CD 717 is a leopard-sized $2^{\text {nd }}$ metacarpal that is slightly more robust than the 'paw', but less robust than KB 5333U (Megantereon). There are minor differences in morphology between it and CD 1500, but they are much more similar to each other than to any other specimens. CD 5703 is a proximal $3^{\text {rd }}$ metacarpal that is very similar to CD 1524 and is clearly not leopard or cheetah. CD 682 is a proximal left $5^{\text {th }}$ metacarpal that is very similar to CD 3271, but also similar to Makapansgat specimen ' 14 ' identified as Dinofelis. CD 1501 is the proximal part of a dew claw first phalanx. It has two clear proximal facets, while lion and leopard have only one. It is larger than the cheetah and is therefore most likely to be machairodont.

Subfamily PANTHERINAE Pocock, 1917

Genus Panthera Oken, 1816

Panthera leo (Linnaeus, 1758) - Lion

Material. Postcranial: CD 10783 a right $1^{\text {st }}$ Metacarpal; CD 3879 and CD 10814 both $1^{\text {st }}$ phalanges.

Diagnosis and discussion

CD 10783 is a very large $1^{\text {st }}$ metacarpal. Illustrations of Dinofelis piveteaui (Werdelin \& Lewis 2001: Fig 19G) and Homotherium (Ballesio 1963) show that the facet for the $2^{\text {nd }}$ 
metacarpal is medially placed in these machairodonts while in CD 10783 and the pantherines it covers much of the proximal surface. In the three lion MC1s available for comparison, it closely matches AZ 771, except that the fossil is from a larger animal (total length $=44.3 \mathrm{~mm}$, distal breadth 18.3mm), although it differs from BPIc186 and AZ 421 (also lions). CD 3879 is slightly damaged proximally and CD 10814 is complete. They are both from large, lionsized felids, although the depressions on the medial and lateral sides of the distal articulation are much deeper than those seen in the modern lion. They are considerably larger than the phalanges identified as Dinofelis from Kromdraai B (KB 6036, KB 6037, KB 6038) and do not appear to be Homotherium (Ballesio 1963). These specimens are all referred to Panthera leo, but note comments below regarding large pantherines in Africa.

\section{Genus Panthera.}

\section{Panthera cf. P. leo}

Material: CD 8282, left $5^{\text {th }}$ metatarsal.

\section{Diagnosis and discussion}

CD 8282 is a very large pantherine metatarsal. There are minor morphological differences between CD 8282 and the modern lions - the proximal articulation is more ventrally placed in the fossil, and the MT4 facet is round in CD 8282 and more oval in the lion. However, it is clearly not Homotherium spp., as it lacks the distinctive rectangular proximal articulation that are seen in that genus, and it is almost twice the size of the Drimolen Dinofelis specimens. Broom (1948) designated a large pantherine canine of uncertain provenance (either from Bolts Farm or Sterkfontein) as Felis shawi Broom, 1948, and Ewer (1956) referred some large lion-like specimens from Kromdraai A to Panthera ?shawi. Turner (1986) examined fossil lion material from Sterkfontein and Swartkrans and indicated that the South African fossil lions were larger than their modern conspecifics and similar in size to the Middle and 
Late Pleistocene lions from Europe. However, Geraads (2008, in press) discusses the possibility of a large, non-lion pantherine in North Africa, and it is also possible that the large Cooper's specimen represents this taxon.

Genus Panthera Oken, 1816

Panthera pardus (Linnaeus, 1758) - Leopard

Material: Postcranial: CD 3277, left proximal radius; CD 7369, left radius - distal epiphysis only; CD 1526, right ulna - distal epiphysis only; CD 1956, patella; CD 5957, $3^{\text {rd }}$ Metatarsal; CD 3836, $4^{\text {th }}$ Metatarsal; CD 8288, and CD 1537, both $1^{\text {st }}$ phalanges.

\section{Description and taxonomic assignment}

Forelimb: CD 3277 is a proximal radius. It is smaller than the East African Dinofelis specimens illustrated in Werdelin \& Lewis (2001) although the angle between the shaft and head is similar. The Kromdraai Megantereon radii (KB 53330 and KB 5336) are both larger and have a more robust radial tuberosity than is seen in CD 3277. A distal radial epiphysis (CD 7369) has a large ulnar facet, indicating that is it not a cheetah, and overall shape of the carpal facets is squarish, whereas it is more rectangular in Dinofelis and Megantereon. Morphology of the radius, both proximally and distally appears to be quite variable in modern leopards, particularly the outline and depth of the proximal articulation, but CD 3277 and CD 7369 are both most similar to modern leopards. An isolated distal epiphysis from a right ulna (CD 1526) is also assigned to P. pardus, as the styloid process in Dinofelis is much more bulbous and Dinofelis is larger overall. 
Hindlimb. CD 1956 is a tear-drop shaped patella with some damage to the dorsal surface. It is substantially smaller than KB 5377, a patella described as cf. Megantereon from Kromdraai B. No Dinofelis patellae were available for study, but CD 1956 is very similar to a modern leopard (AZ 420) and is therefore been referred to that species. Two metatarsals have also been referred to $P$. pardus. CD 5957 is a complete right $3^{\text {rd }}$ metatarsal, broken into three pieces. It is very gracile in comparison with Dinofelis, of a similar length but slenderer. The posterior facet of the MT4 articulation is curved, in DN17 it is not curved, while in KB 5334B (Megantereon whitei) it is flat and angled medially. Again the morphology of the leopards appears to be highly variable, but for a medium-sized felid this specimen is much more like $P$. pardus than any of the other similar sized species. CD 3836 is the proximal articulation plus $1 / 3^{\text {rd }}$ of the shaft of a left $4^{\text {th }}$ metatarsal. It has some slight pathological bone growth on the dorsal surface and the articulation for the $5^{\text {th }}$ metacarpal. Despite this it is clear that it is neither Dinofelis nor Megantereon - Dinofelis (DN 14) has a much more rounded articulation for the $3^{\text {rd }}$ metatarsal, while this articulation is flatter and the proximal articulation is a little larger in Megantereon (KB 5339C). CD 1537 is a complete $1^{\text {st }}$ phalanx with a small chip from the dorsal surface, while CD 8288 has a small amount of damage on the distal condyle. Both are very good matches for modern leopard.

\section{cf. Panthera pardus (Linnaeus, 1758) - Leopard}

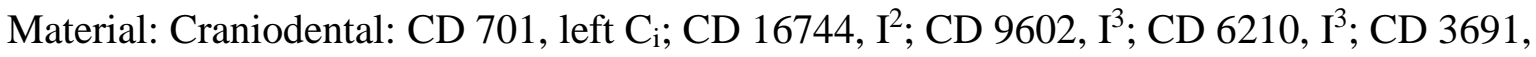
posterior portion of cranium. Postcranial: CD $6672+$ CD 6673, refitting fragments of a right distal femoral epiphysis; CD 2053, left distal femoral epiphysis; CD 5996, humerus, proximal diaphysis only. 


\section{Diagnosis and discussion}

These specimens are all leopard-sized. CD 701 is the enamel cap of a lower canine, there is no dentine infill and the crown is completely unworn, indicating it was unerupted. The crown is unkeeled (so it is not Dinofelis) and has one lingual groove near the tip, but it is small in comparison with modern leopards. CD 16744 is a small and heavily worn left $\mathrm{I}^{2}$ with pyrolusite encrustation. CD 6210 is a broken and worn right $\mathrm{I}^{3}$ with pyrolusite encrustation. The crown is strongly curved with a clear internal cingulum. CD 9602 is a large left $\mathrm{I}^{3}$ with a possible accessory cusp. It is slightly narrower medio-laterally than a modern leopard (AZ 420) and also lacks the internal cingulum. CD 3691 is the posterior portion of a cranium, with both auditory bullae, both occipital condyles, and a small portion of the sagittal crest. CD 6672 and CD 6673 are refitting fragments of a right distal femoral epiphysis. They are the same size and morphology as CD 2053, a left distal femoral epiphysis, suggesting that they may be antimeres. They are good, but not exact, matches for Panthera pardus, however there were no distal Megantereon femora available to compare them with. CD 5996 is a humeral diaphysis in three pieces, it is entirely unfused and is a good match for a male leopard of similar age (AZ 420), however the medial ridge appears much more pronounced in the modern specimen.

Subfamily FELINAE Fischer, 1817

Genus Acinonyx Brookes, 1828

Acinonyx jubatus (Schreber, 1775)

Material: Craniodental: CD 3871, left $\mathrm{P}^{4}$ (Fig. 5H-I); CD 9614 left $\mathrm{I}_{3}$. 


\section{Diagnosis and discussion}

CD 3871 is an almost complete $\mathrm{P}^{4}$, just lacking the mesial border of the protocone. Despite this it can be seen that the protocone was much reduced in comparison with the pantherines. The ectoparastyle is very large, in contrast to Megantereon where there is no ectoparastyle (Christiansen \& Adolfssen 2007; KA 64 pers. obs.). Other than the protocone being slightly more anteriorly placed in CD 3871 it is a very good match for the modern cheetah. The isolated lower incisor CD 9614 has a clear accessory cusp on the buccal surface and is a robust tooth with a relatively short crown. Other than the slight difference in the protocone position on the $\mathrm{P}^{4}$, the Cooper's $\mathrm{D}$ specimens match those of the modern cheetah, and are referred to this species.

Genus Caracal Gray, 1843

Caracal caracal (Schreber, 1776) - Caracal

Material: CD 9172, a left $1^{\text {st }}$ metacarpal.

\section{Description and taxonomic assignment}

This specimen is complete, but heavily encrusted with pyrolusite. From the size (total length $=18.5 \mathrm{~mm}$ ) and visible morphology it is a good match for caracal. Note that the specimen (CD 324) tentatively identified as a lower carnassial of a caracal in Berger et al. (2003) is the posterior portion of a very heavily damaged $\mathrm{P}^{4}$ and is not identifiable.

Genus Felis Linnaeus, 1758.

Felis silvestris lybica Forster, 1780 - African wild cat.

Material: CD 691, left Cs.

Description and taxonomic assignment 
This is a small upper canine with a broken tip. One lingual and two buccal grooves are visible in the enamel, it is clearly a small felid and based on its size, it is most likely to be $F$. s. lybica the African wildcat.

Genus Felis Linnaeus, 1758.

\section{Felis sp.}

Material. CD 675, anterior fragment of right mandible with canine alveolus, $\mathrm{P}_{3}$ and damaged $\mathrm{P}_{4}$ (Fig. 5J-K); CD 17790, proximal right femur and half shaft.

CD 675 is a right mandible fragment from a very small felid (Fig. 5J-K). The anterior portion of the mandible is present, including a damaged canine alveolus, complete $\mathrm{P}_{3}$ and a damaged $\mathrm{P}_{4}$. There are two mental foramina, one is large and halfway along the symphysis, while the other is much smaller and situated below the anterior root of the $\mathrm{P}_{3}$. The $\mathrm{P}_{4}$ is broken vertically after the protocone, and the corpus of the mandible is also broken here. The $\mathrm{P}_{3}$ lacks an anterior accessory cusp and has almost no anterior cingulum, although the posterior accessory cusp and posterior cingulum are present. The $\mathrm{P}_{4}$ has a well-defined anterior accessory cusp but also lacks the anterior cingulum. In Felis s. lybica the anterior accessory cusp is present on the $\mathrm{P}_{3}$, the protocones are proportionally higher than that seen on CD 675 , and the mandible is less gracile. However, the elongation of the protocone crown in Felis nigripes (Burchell, 1824) as shown in Salles (1992) and discussed in relation to the Malapa specimen in Kuhn et al. (2011) is not seen in this specimen. While there are minor morphological differences between CD 675 and the F.s. lybica specimens available to study, metrically the specimen falls into the area of overlap between the two species (Fig. 6). It is therefore referred to Felis sp. (F. sylvestris lybical F. nigripes size). CD 17790 is a small proximal femur. The shape of the greater trochanter and the slight curve of the shaft suggest 
that it is felid, and it is a good match for both the F. s. lybica and F. nigripes specimens in the Ditsong museum collections.

\section{FELIDAE indet.}

Many of the specimens listed below as Felidae indet. may be machairodont, but a lack of comparative material means that they are currently only identified to the family level.

Felidae indet. large (lion to Dinofelis-sized)

Material: CD 1944, left $3^{\text {rd }}$ metacarpal; CD 1522, right $3^{\text {rd }}$ metatarsal fragment; CD 3847 , distal metapodial; CD 5354, left calcaneum fragment; CD 3680, left cuboid; CD 1549, right $3^{\text {rd }}$ metatarsal; CD 1965, right pisiform; CD 3902 left scapholunar; CD 18837, right distal

tibia fragment; CD 3861, right astragalus; CD 9860, sesamoid; First phalanges: CD 9729, CD 1532, CD 1547, CD 3867, CD 5955, CD 6760, CD 3223, CD 17479; CD 1550, CD 5974, CD 728, CD 5958, CD 3842; Second phalanges: CD 3869, CD 5439, CD 367, CD 3890, CD 3840, CD 16956, CD 9929.

\section{Description}

CD 1944 is the proximal portion of a large $2^{\text {nd }}$ metacarpal. The proximal articulation is slightly damaged dorsally and is also greatly laterally expanded, more so than any Dinofelis specimens in Werdelin \& Lewis (2001). CD 1522 is a large proximal $3^{\text {rd }}$ metatarsal fragment. There are similarities to both Dinofelis and Acinonyx, however as only the anterior portion of the articulation is present it is difficult to identify it more precisely. CD 3847 is a heavily gnawed distal metapodial from a large felid. CD 5354 is a short, robust left tuber calcis from a Dinofelis-sized calcaneum. CD 3861, an astragalus, is from a larger cat and does not seem to match any of the machairodonts. CD 3680, a left cuboid, is intermediate in size between 
the lion and leopard and appears very different to $16201 \mathrm{M}$ (D. darti from Makapansgat). CD 1549 is an almost complete metatarsal, just lacking the dorsal portion of the proximal articulation. It has similarities to both Dinofelis (DN 17) and P. pardus, however the shaft is much more angular in CD 1549 than is seen in these two taxa. CD 1965 is a right pisiform with a flattened head, much more so than the lion. It may represent Dinofelis but there is a lack of suitable comparative material. CD 3902 is a good size match for an un-numbered Dinofelis scapholunar from Makapansgat, but the orientation and depth of facets is very different. CD 18837 is a distal tibial articulation with a fragment of shaft. It is intermediate in size between leopard and Dinofelis, with very pronounced ridges on the shaft and broad distal processes. CD 9860 is a lion-sized sesamoid, it is very similar to a specimen from a lion forefoot (AZ 771), however there are no machairodont sesamoids to compare it with. Phalanges CD 9729, CD 3869 and CD 9929 are robust and lion-like, yet CD 9729 and CD 9929 are almost triangular in cross-section. First and second phalanges CD 1532, CD 1547, CD 3867, CD 5955, CD 6760, CD 3223, CD 17479, CD 1550, CD 5974, CD 3842, CD 3869, CD 5439, CD 367, CD 3890 CD 3840 and CD 16956, are all shorter than lion, but broader than leopard - they may represent Dinofelis. CD 728 is a robust $1^{\text {st }}$ phalange that is broader and shorter than lion, but does not match the Kromdraai Dinofelis material, or published figures of Homotherium (Ballesio 1963). CD 5958 is a complete $1^{\text {st }}$ phalange that looks more similar to the Senèze Homotherium material than any other taxon.

Felidae indet.(medium-sized (Megantereon to leopard-sized)

Material: Craniodental: CD 1892, mandible fragment with condyle and angle of the ramus; CD 8305, left $\mathrm{P}_{3}$; Postcranial: CD 1623, left $1^{\text {st }}$ metacarpal; CD 6757, $1^{\text {st }}$ phalanx; CD 1534, a right pisiform; CD 3996, right ulna fragment; CD 1530, left ulna fragment; CD 5712, left 
intermediate cuneiform; CD 3205, metapodial lacking proximal articulation; Distal metapodial fragments: CD 7303, CD 3846, CD 3200, CD 7889, CD 7320, CD 13373; CD 640, CD 688 and CD 1626; $1^{\text {st }}$ phalanges: CD 17068, CD 1957, CD 3863, CD 1543, CD 2017 (distal only), CD 3864, CD 19951, CD 20004 (damaged), CD 7352, CD 3236, CD 3886 (dorsal surface only); $2^{\text {nd }}$ phalanges, CD 699, CD 5727, CD 5486, CD 7345, CD 11736, CD 1546, CD 1946, CD 1539, CD 17230, CD 3286, CD 1945, CD 7361; $3^{\text {rd }}$ phalanges: CD 7356, CD 6756, CD 7304, CD 5793, CD 11185, CD 3197; CD 5671, right intermediate cuneiform; CD 13342, left $2^{\text {nd }}$ metacarpal.

\section{Description}

CD 1892 is a posterior fragment of a mandible, lacking the coronoid process. The condyle is lozenge-shaped and there is only a short distance between the condyle and the angle of the ramus. It does not appear to be Megantereon, and is intermediate in size between caracal and leopard. CD 8305 is a small complete lower premolar, with a large upright protocone, small but distinct anterior and posterior accessory cusps and a posterior cingulum. All cusps are in a straight line from front to back. It is most similar to a cheetah tooth, except that the cheetah lacks a posterior cingulum, and the anterior accessory cusp is greatly reduced in comparison to the posterior accessory cusp, while in the cheetah they are usually of similar size. It refits into the $\mathrm{P}_{3}$ alveolus of CD 18836 (here identified as Dinofelis $c f$. aronoki), although it is from the opposite side. It is much less robust than the equivalent tooth in Dinofelis barlowi (STS 131), and the anterior cusp is in line with the protocone rather than being lingually placed as seen in $D$. aronoki. The protocone is much higher than that seen in the Motsetse D. piveteaui specimens, and it is considerably shorter $(\mathrm{L}=$ approximately $11 \mathrm{~mm})$ than any published Dinofelis $\mathrm{P}_{3}$ from South Africa (see Lacruz et al. 2006 for comparative measurements). It has therefore been referred to Felidae indet., as it may represent either Acinonyx or Dinofelis. CD 
3996 and CD 1530 are both olecraneon processes from a right and left ulna respectively. They may be antimeres, as they are the same size and the proximal epiphyseal line is still visible on both. There are similarities with both leopard and the Senèze Megantereon specimen and thus they are referred to Felidae indet. CD 5712 is a left intermediate cuneiform with damage to the head. Both the cuboid facet and the cuneiform facets are larger and extended more proximally than those of the modern leopard, however the head is much more expanded in Megantereon (KB 6016 and KB 6017) than is seen in CD 5712. CD 1623 is a complete $1^{\text {st }}$ metacarpal, the proportions of the proximal facet make it more similar to a machairodont than a pantherine. However, with no $P$. pardus specimens for comparison it is listed here as Felidae indet. CD 6757 is an asymmetric $1^{\text {st }}$ phalanx that has been distally gnawed. First phalanges CD 17068 and CD 1957, and second phalanges CD 699, CD 5727, CD 5486, CD 7345, CD 11736, CD 7352 and CD 3236 are all similar to modern Acinonyx, but Megantereon cannot be excluded. First phalanges CD 3863, CD 1543, CD 19951 and CD 20004 may represent leopard, while CD 2017 and CD 3864 are not leopard or cheetah and may be machairodont. Second phalanges CD 1546, CD 1946, CD 1539, CD 17230 and CD 3286 are all similar to modern leopard specimens, but Megantereon is also a possibility. CD 1945 and CD 7361 are both felid second phalanges that are smaller than leopard. Six $3^{\text {rd }}$ phalanges (CD 7356, CD 6756, CD 7304, CD 5793, CD 11185, CD 3197) are leopard to cheetah size, but are not cheetah. There are two morphotypes, with CD 7356 and CD 6756 more similar to each other, and the remaining four also appearing alike. CD 1534, a pisiform, is strongly curved proximally. CD 3205 is a metapodial in two pieces, lacking the proximal end. The shaft is strongly curved and almost triangular in cross-section suggesting it may be a $5^{\text {th }}$ metatarsal. Nine specimens $(C D 7303$, CD 3846, CD 3200, CD 7889, CD 7320, CD 13373, CD 640, CD 688 and CD 1626) are all probable felid distal metapodial condyles, some with fragments of shaft. It is worth noting that CD 7889 is unfused and therefore 
represented a younger individual, and that CD 640 and CD 688 are larger than the others and may plausibly be large leopard or small Dinofelis. CD 5671 is one half of an intermediate cuneiform, it is similar in morphology to leopard, but larger, and there are no Dinofelis cuneiforms to compare it with. CD 13342 is the proximal portion of a left $2^{\text {nd }}$ metatarsal. It is slightly damaged and may have been gnawed. It is similar to CD 1500 (here assigned to Machairodontinae indet.), but the process is slightly sharper in CD 13342 (which is more like DN 772), and the facet for the $1^{\text {st }}$ metacarpal is not quite as square as the other Cooper's D specimens. It is therefore assigned to Felidae indet.

Felidae indet. small (Felis sylvestris to caracal-sized)

Material: Craniodental: CD 3258, a right $\mathrm{P}^{3}$; CD 13517, broken left $\mathrm{C}_{\mathrm{i}}$; Postcranial: CD 9431, right distal femur; CD 1592, left calcaneum; CD 13516, $1^{\text {st }}$ phalanx; CD 1492, $2^{\text {nd }}$ phalanx; CD $19227,2^{\text {nd }}$ phalanx.

\section{Description}

CD 3258 is an isolated $\mathrm{P}^{3}$, with small anterior and posterior accessory cusps, a cingulum and a relatively low protocone. There is a slight bulge of enamel on the lingual surface, just over the posterior root. It is similar to a leopard $\mathrm{P}^{3}$ but much smaller. A similar tooth was found at Drimolen (DN 743) and also assigned to Felidae indet. CD 13517 is a caracal-sized $\mathrm{C}_{\mathrm{i}}$ with two ridges visible at the base of the crown, one distal and one lingual; the rest of the crown is broken. CD 9431 is a heavily damaged distal femoral articulation. It has a slight groove on the medial condyle that only appears to be present in cats and is caracal-serval sized. CD 1592 is a left calcaneum with very long facets for the articulation with the astragalus. It is most similar to caracal and serval, but it is difficult to choose between them. CD 13516 is a short, but very broad, first phalanx, it does not match any of the extant felid taxa. CD 1492 
and CD 19227 are both similar to caracal second phalanges, but there are no serval specimens available for comparison.

\section{Discussion}

In comparison with the original species lists published for Cooper's D in Berger et al. (2003) and de Ruiter et al. (2009), all taxa are still present, but with some modifications. The minimum numbers of individuals for the Cooper's D felids recorded in Table 3 are lower than those reported in de Ruiter et al. (2009), with the exception of Megantereon whitei, where the MNI has increased from one to two. The reduction in the other taxa (particularly leopard) is owing to the uncertainty of attribution of fragmentary postcranial remains which may well represent leopard, but the possibility that they represent Megantereon cannot be excluded based on the available comparative material.

The small mandible referred to Felis lybica in Berger et al. (2003) is here described as Felis sp. It is intermediate in size between Felis sylvestris lybica and Felis nigripes and cannot be assigned to either with confidence. Until recently there was no fossil record of the black footed cat (F. nigripes) in South Africa, however it has now been reported from Malapa in the Cradle (Kuhn et al. 2011). As a species it is a southern African endemic and is the smallest of the African Felidae.

The postcranial lion remains are assigned to P. leo (in agreement with de Ruiter et al. 2009) rather than cf. P. leo as originally reported in Berger et al. (2003). Lions, despite being Africa's largest cat, are relatively rare in the fossil record. In the Cradle of Humankind (Gauteng), lion has also been reported from Gladysvale (Lacruz, 2009), Swartkrans Member 1 Lower Bank (Turner 1993) and at Sterkfontein in the Silberberg Grotto, Member 4 (Turner 
1986, 1987a), Member 5 East (Oldowan Infill) and Member 5 West (O’Regan 2007).

Although the dating of deposits at Sterkfontein is not straightforward, the most recent estimates (as summarised in Reynolds \& Kibii 2011) would place the Member 5 lions at a similar or slightly later date than those at Cooper's D.

Members of the genus Acinonyx are rarely found as fossils in Africa, yet it has a richer record in Europe (Acinonyx pardinensis (Croizet \& Jobert, 1828)). Two species of cheetah are known from the African fossil record - Acinonyx aicha Geraads, 1997, which is so far found only at Ahl al Oughlam in North Africa (Geraads 1997), and specimens from other sites in Gauteng, South Africa which have been referred to the modern species A. jubatus (Turner 1986, 1987a, 1993). These are from the Silberberg grotto, Sterkfontein (Turner 1987a), and Swartkrans members 2 (Turner 1986) and 3 (Turner 1993), while de Ruiter (2003) also lists A. jubatus in the Swartkans Member 1 hanging remnant. The specimens identified here are very similar to the modern cheetah and given the doubts over the provenance of the cheetah from the hanging remnant (as discussed in de Ruiter 2003) and the difficulties dating the Swartkrans cave deposits, particularly Members 2 and 3 (de Ruiter 2003; Herries et al. 2009), the Cooper's D specimens may be the earliest well-dated material of the modern species in Africa.

The machairodonts are well represented in the Cooper's D deposits, with the recovery and identification of several more specimens of a particularly small Megantereon whitei as first discussed by Hartstone-Rose et al. (2007). However, the most significant felid finding from the site is the material described here as Dinofelis cf. aronoki. The sabre-toothed cat genus Dinofelis arose in the Late Miocene, and its biogeographic range extended from North America to Southern Africa, before it became extinct in the Pleistocene (Werdelin \& Lewis 
2001). Africa appears to have been the evolutionary centre of the genus, with five species (plus another 3 suggested but unnamed by Werdelin \& Lewis (2001)) recorded from the continent. There is some geographic variation in taxa, with $D$. barlowi, and $D$. darti only being present in South Africa, while $D$. petteri and $D$. aronoki have thus far only been recorded in East Africa, and the latest member of the genus D. piveteaui, known from both East and South African deposits. If the new material described here is conspecific with Dinofelis aronoki from East Africa, it it originated in East Africa and dispersed to South Africa, as has also been suggested for D. piveteaui. However, if further work identifies the South African material as a new species, then this has implications both for the evolution of D. piveteaui and for the evolution of the genus Dinofelis in Southern Africa. If the Koobi Fora and Cooper's D taxa are related, then it is plausible that $D$. aronoki is ancestral to $D$. piveteaui, which would be the most logical scenario as $D$. piveteaui is the most derived of all the Dinofelis species. If they are not related then the species at Cooper's D and Drimolen may represent a separate southern African lineage that parallels, but is not directly related to, $D$. piveteaui. Each scenario is dependent on the date of the sites and the morphological traits for each species. There is a small, but unlikely possibility that the differences between $D$. piveteaui and $D$. cf. aronoki could be sexual dimorphism and that they in fact represent males and females of the same species. However, for the dimorphism to be most pronounced in the carnassials would seem highly unlikely, as also discussed by Lacruz et al. (2006). The presence of an additional species of Dinofelis in southern Africa at 1.5-1.4 Ma is unexpected and is contrary to the patterns of decline seen in the other machairodont taxa, which were either extinct or almost so, by this point. The particularly small and late Megantereon whitei from the site, could be contrasted with the larger Dinofelis specimens, and may indicate some form of competition between the taxa. However, the exact dates of D. piveteaui in South Africa remain unclear, as both Kromdraai A and Motsetse are only dated by biostratigraphy, 
with no radiometric dates. This makes it difficult to elucidate the chronology and relationships between the taxa at the present time.

\section{Conclusion}

Felid fossils are often rare in palaeontological sites, but 155 have been identified from Cooper's D. They are notable for the wide variety of taxa represented including two sabretoothed cats (Megantereon and Dinofelis), as well as most of the extant taxa found in southern Africa today (lion, leopard, cheetah, caracal). Dinofelis cf. aronoki is present at two sites within the Cradle - Cooper's D and Drimolen, and takes the known number of PlioPleistocene Dinofelis taxa in the cradle sites to three. There is clearly still much to learn, both about the size reduction and extinction of Megantereon, and about the radiation and subsequent extinction of the genus Dinofelis.

\section{Acknowledgements}

HO'R's Research into the Coopers D Felidae was supported by Liverpool John Moores University Early Career Researcher Award in 2010, and a small grant from the Palaeoanthropological Scientific Trust (PAST). CMS would like to thank the support of the DST-NRF Centre of Excellence in Palaeosciences. Many thanks to Bernhard Zipfel (BPI), Stephany Potze (Ditsong), Shaw Badenhorst (Ditsong), Teresa Kearney (Ditsong) for hospitality and access to material at Wits and Ditsong Museum. We thank Job Kibii for discussions of the Kenyan material, and Ron Clarke and Kathy Kuman for access to Goldsmith's Farm material and Colin Menter for access to the Drimolen specimens. All photographs are by Brett Eloff. This paper is dedicated to the memory of Alan Turner, both colleague and friend. 


\section{References}

ANDREWS C. W. 1916. - Note on a new baboon (Simopithecus oswaldi, gen. et. sp. n.) from the (?) Pliocene of British East Africa. Annals and Magazine of Natural History, Eighth series 18: 410-419.

BALlESIO R. 1963. - Monographie d'un Machairodus du gisement villafranchien de Senèze: Homotherium crenatidens Fabrini. Travaux du Laboratoire de Géologie de la Faculté des Sciences de Lyon, NS 9, 1-129.

Berger L.R., De Ruiter D. J., Steininger C. M. \& HANCOX, J. 2003. - Preliminary results of excavations at the newly investigated Cooper's D deposit, Gauteng, South Africa. South African Journal of Science 99: 276-278.

BROOKES J. 1828. - A catalogue of the anatomical and zoological museum. Joshua Brookes, London.

BRoOM R. 1937. - On some new Pleistocene mammals from limestone caves of the Transvaal. South African Journal of Science 33: 750-768.

Broom R.1938. - The Pleistocene anthropoid apes of South Africa. Nature 142: 377-379

Broom R. 1948. - Some South African Pliocene and Pleistocene mammals. Annals of the Transvaal Museum 21: 1-38. 
BOWDICH T. E. 1821. - An analysis of the natural classifications of Mammalia for the use of students and travelers. J. Smith, Paris.

BURCHELL W. J. 1824. - Travels in interior of Southern Africa. Longman, Hurst, Rees, Orme, Brown and Green, London 2: 509-592.

CHRISTIANSEN P. \& AdOLFSSEN J. S. 2007. - Osteology and ecology of Megantereon cultridens SE311 (Mammalia; Felidae; Machairodontinae), a sabrecat from the Late Pliocene - Early Pleistocene of Senéze, France. Zoological Journal of the Linnean Society 151: 833884.

CROIZET J. B. \& Jobert A. C. G. 1828. - Recherches sur les ossemens fossiles du départment du Puy-de-Dôme 1: 1-224.

CUVIER G. 1824. - Recherches sur les ossemens fossils, où l'on rétablit les charatères de plusieurs animaux don't les revolutions du globe ont détruit les espèces 4: 1-514.

De Ruiter D. J., Pickering R., Steininger C. M., Kramers J. D., Hancox P. J., Churchill S. E., Berger L. R. \& BACKwELL L. 2009. - New Australopithecus robustus fossils and associated U-Pb dates from Cooper's Cave (Gauteng, South Africa). Journal of Human Evolution 56: 497-513.

DE RUITER D. J., SPONHEIMER M. \& LEE-THORP J. A. 2008. - Indications of habitat association of Australopithecus robustus in the Bloubank Valley, South Africa. Journal of Human Evolution 55: 1015-1030. 
DE RUITER D. J. 2003. - Revised faunal lists for Members 1-3, Swartkrans, South Africa. Annals of the Transvaal Museum 40: 29-41.

DeSilva J. M., Steininger C. M. \& PAtel B. A. 2013. - Cercopithecoid primate postcranial fossils from Cooper's D, South Africa. Geobios 46: 381-394.

EWER R. F. 1955. - The fossil carnivores of the Transvaal caves: Machairodontinae. Proceedings of the Zoological Society of London 125: 587-615.

EWER, R. F. 1956. - The fossil carnivores of the Transvaal caves: Felinae. Proceedings of the Zoological Society, London 126: 83-95.

FAlCONER H. \& CAUTLEy P. T. 1836. - Note on the Felis cristata, a new fossil tiger from the Sivalik hills. Asiatic researches 19: 135-142.

FISCHER, G. 1817. - Adversaria Zoologica. Mémoires de la Société impériale des naturalistes de Moscou 5: 357-446.

Folinsbee K. E. \& Reisz R. R. 2013. - New craniodental fossils of Papionin monkeys from Cooper's D, South Africa. American Journal of Physical Anthropology 151: 613-629. 
FORSTER G. 1780. - Beschreibung des rothen Baumläufers von der Insel O-Waihi. In:

BufFON G. L. L. de (ed.), Naturgeschichte der vierfüssigen Thiere 6, 313. Joachim Pauli, Berlin.

GERAADS D. 1997. - Carnivores du Pliocène terminal de Ahl Al Oughlam (Casablanca, Maroc). Geobios 30: 127-164.

GERAADS D. 2008. - Plio-Pleistocene Carnivora of northwestern Africa: a short review. Comptes Rendus Palevol 7: 591-599.

GERAADS D. in press. - Pleistocene Carnivora (Mammalia) from Tighennif (Ternifine), Algeria. Geobios http://dx.doi.org/10.1016/j.geobios.2016.09.001

GILL T. 1872. - Arrangement of the families of mammals with analytical tables. Smithsonian miscellaneous collections 11, 1-98.

GRAY J. E. 1843. - List of the specimens of Mammalia in the collections of the British Museum. George Woodfall and Son, London. p. 46.

Hartstone-Rose A., Werdelin L., De Ruiter D. J., Berger L. R. \& Churchill S. E. 2009. - The Plio-Pleistocene ancestor of wild dogs, Lycaon sekowei. Journal of Paleontology 84: 299-308. 
Hartstone-Rose A., De Ruiter D. J., Berger L. R. \& Churchill S. E. 2007. - A sabretooth felid from Coopers Cave (Gauteng, South Africa) and its implications for Megantereon (Felidae: Machairodontinae) taxonomy. Palaeontologia Africana 42: 99-108.

HERRIES A. I. R., CURNOE D. \& ADAMS J. W. 2009. - A multidisciplinary seriation of early Homo and Paranthropus bearing palaeocaves in South Africa. Quaternary International 202: $14-28$.

Kuhn B. F., Werdelin L., HARTSTONE-Rose A., LACRUZ R. S. \& Berger L. R. 2011. Carnivoran remains from the Malapa Hominin Site, South Africa. PLoS ONE 6 (11): e26940.

Kuhn B. F., Werdelin L., Steininger, C. in press. - Fossil Hyaenidae from Cooper's Cave, South Africa, and the palaeoenvironmental implications. Palaeobiodiversity and Palaeoenvironments doi:10.1007/s12549-016-0247-y

LACRUZ R. 2009. Panthera leo (Mammalia: Felidae) remains from the Gladysvale Cave, South Africa. Annals of the Transvaal Museum 46: 121-124.

LACruZ R., Turner A. \& Berger L. R. 2006. - New Dinofelis (Carnivora: Machairodontinae) remains from Sterkfontein Valley sites and a taxonomic revision of the genus in Southern Africa. Annals of the Transvaal Museum 43: 89-106.

LINNAEUS C. 1758. - Sistema naturae, tenth ed. Stockholm. 
OKEN L. 1816. - Okens Lehrbuch der Naturgeschichte. Theil 3: Zoologie. Erklärung der Kupfer, Leipzig and Jena.

O’REGAN H. J. 2002. - A phylogenetic and palaeoecological review of the Pleistocene felid Panthera gombaszoegensis. Unpublished PhD thesis, Liverpool John Moores University, UK.

O’Regan H. J. 2007. - Revision of the Carnivora from Member 5, Sterkfontein, South Africa, based on a re-assessment of the published material and site stratigraphy. Annals of the Transvaal Museum 44: 209-214.

O’Regan H. J. \& MenteR, C. 2009. - Carnivora from the Plio-Pleistocene hominin site of Drimolen, Gauteng, South Africa. Geobios 42: 329-350.

O’Regan H. J., Cohen, B. F. \& Steininger, C. M. 2013. - Mustelid and Viverrid remains from the Pleistocene site of Cooper's D, Gauteng, South Africa. Palaeontologia Africana 48: $19-23$.

Palmqvist P., Torregrosa V., Perez-Claros J. A., Martinez-Navarro B. \& Turner A. 2007. - A re-evaluation of the diversity of Megantereon (Mammalia, Carnivora, Machairodontinae) and the problem of species identification in extinct carnivores. Journal of Vertebrate Paleontology 27: 160-175 
Pocock R. I. 1917a. - The classification of the existing Felidae. Annals and Magazine of Natural History, series 8, 20:329-350.

REYNOLDS S. C. \& KIBII J. M. 2011. - Sterkfontein at 75: review of paleoenvironments, fauna, dating and archaeology from the hominin site of Sterkfontein (Gauteng Province, South Africa). Palaeontologia africana 46: 59-88.

SALLES L. O. 1992. - Felid phylogenetics: Extant taxa and skull morphology (Felidae, Aeluroidea). American Museum Novitates 3047: 1-67.

SCHREBER, J. C. D. 1775. - Die Säugethiere in Abbildungen nach der Natur, mit Beschreibungen, 2. Walther, Erlangen.

SCHREBER, J. C. D. 1776. - Die Säugethiere in Abbildungen nach der Natur, mit Beschreibungen, 3. Walther, Erlangen.

SHAW J. C. 1939. Further remains of a Sterkfontein ape. Nature 143: 117.

SHAw J. C. M. 1940. Concerning some remains of a new Sterkfontein primate. Annals of the Transvaal Museum 20: 145-156

TOERIEn M.J. 1955. - A sabre tooth cat from the Makapansgat valley. Palaeontologia Africana 3: 43-46 
TURNER A. 1986. - Miscellaneous carnivore remains from Plio-Pleistocene deposits in the Sterkfontein Valley (Mammalia: Carnivora). Annals of the Transvaal Museum 34: 205-225.

TURNER A. 1987a. - New fossil carnivore remains from the Sterkfontein hominid site (Mammalia, Carnivora). Annals of the Transvaal Museum 34: 319-347.

TURNER A. 1987b. - Megantereon cultridens (Cuvier) (Mammalia, Felidae, Machairodontinae) from Plio-Pleistocene deposits in Africa and Eurasia, with comments on dispersal and the possibility of a New World Origin. Journal of Paleontology 61: 1256-1268.

TURNER A. 1993. - New fossil carnivore remains from Swartkrans. In BRAIN, C.K. (ed.) Swartkrans: a Cave's Chronicle of Early Man. Transvaal Museum Monograph, vol. 8, Transvaal Museum, Pretoria, pp. 151-165

VRBA E.S. 1981. - The Kromdraai australopithecine site revisited in 1980; recent investigations and results. Annals of the Transvaal Museum 33: 17-60.

WERDELIN L. \& LEWIS M. E. 2001. - A revision of the genus Dinofelis (Mammalia, Felidae). Zoological Journal of the Linnean Society 132: 147-258.

Werdelin L. \& PeignÉ S. 2010. - Carnivora, in: Werdelin L. \& SANDERS W.J. (eds), Cenozoic Mammals of Africa. University of California Press, Berkeley, pp 602-657.

ZDANSKY O. 1924. - Jungtertiäre Carnivoren Chinas. Paleontologia Sinica series C2: 1-149. 


\section{Figure captions}

Figure 1. Craniodental specimens of Dinofelis cf. aronoki. All scale bars =1cm. CD 19961 in A, buccal; B, Lingual and C, occlusal views; D, maxillary fragment CD 7323b,c,d in buccal view; E, CD 7323b,c,d in occlusal view; F, buccal view of P4 fragment CD 7323a, associated with 7323b,c,d; G, CD 16765a+b a right premaxilla fragment with roots of I1-I3; H, upper canine fragment CD 16769a+b; CD 15696 an isolated P3 in lingual (I) and buccal (J) views; CD 18836 right mandible with P4 and M1 in buccal (K) and occlusal (L) views; CD 19265 left M1 in mandible fragment in buccal (M) and occlusal (N) views.

Figure 2. Postcranial specimens of Dinofelis cf. aronoki. All scale bars $=1 \mathrm{~cm}$. Right third metatarsal (CD 19953) in medial (A) and lateral (B) views; CD 3233, left femur in lateral (C), medial (D) and superior views (E); CD 7359 right ulna fragment in lateral (F) and medial (G) views.

Figure 3. $\log _{10}$ total length of $\mathrm{P}^{4}$ plotted against anterior breadth at the protocone of the $\mathrm{P}^{4}$ for six African Dinofelis species. Data from Werdelin and Lewis (2001), Lacruz et al. (2006) and this study.

Figure 4. $\log _{10}$ total length of $\mathrm{P}^{4}$ plotted against metastyle length of the $\mathrm{P}^{4}$ for six African Dinofelis species. Data from Werdelin and Lewis (2001), Lacruz et al. (2006) and this study.

Figure 5. Craniodental felid specimens, all scale bars = 1cm. Megantereon whitei: CD 5963, buccal view of right mandible (A); CD 5997, buccal view of left mandible (B); CD 10452, buccal (A) and lingual (D) views of M1. cf. Megantereon whitei: CD 10497, left I3 with two 
cusplets on medial surface (E). Machairodontinae indet.: CD 3835, right P3 in lingual (F) and occlusal (G) views. Acinonyx jubatus: CD 3871, left P4 lacking protocone in occlusal (H) and lingual (I) views. Felis sp.: CD 675, right mandible with P3 and partial P4 in buccal (J) and lingual $(\mathrm{K})$ views.

Figure 6. Length of $\mathrm{P}_{3}$ plotted against anterior breadth of $\mathrm{P}_{3}$ for Felis nigripes, Felis silvestris lybica and CD 675, Felis sp.

\section{Table captions}

Table 1. Measurements (in $\mathrm{mm}$ ) of crania and maxillary dentition of all felid specimens from Cooper's D.

Table 2. Measurements (in $\mathrm{mm}$ ) of mandibles and mandibular dentition of all felid specimens from Cooper's D.

Table 3. Postcranial measurements (in $\mathrm{mm}$ ) of all felid specimens from Cooper's D.

Table 4. Total number of identifiable felid specimens (NISP) by taxon, and minimum number of individuals for each species (MNI). 


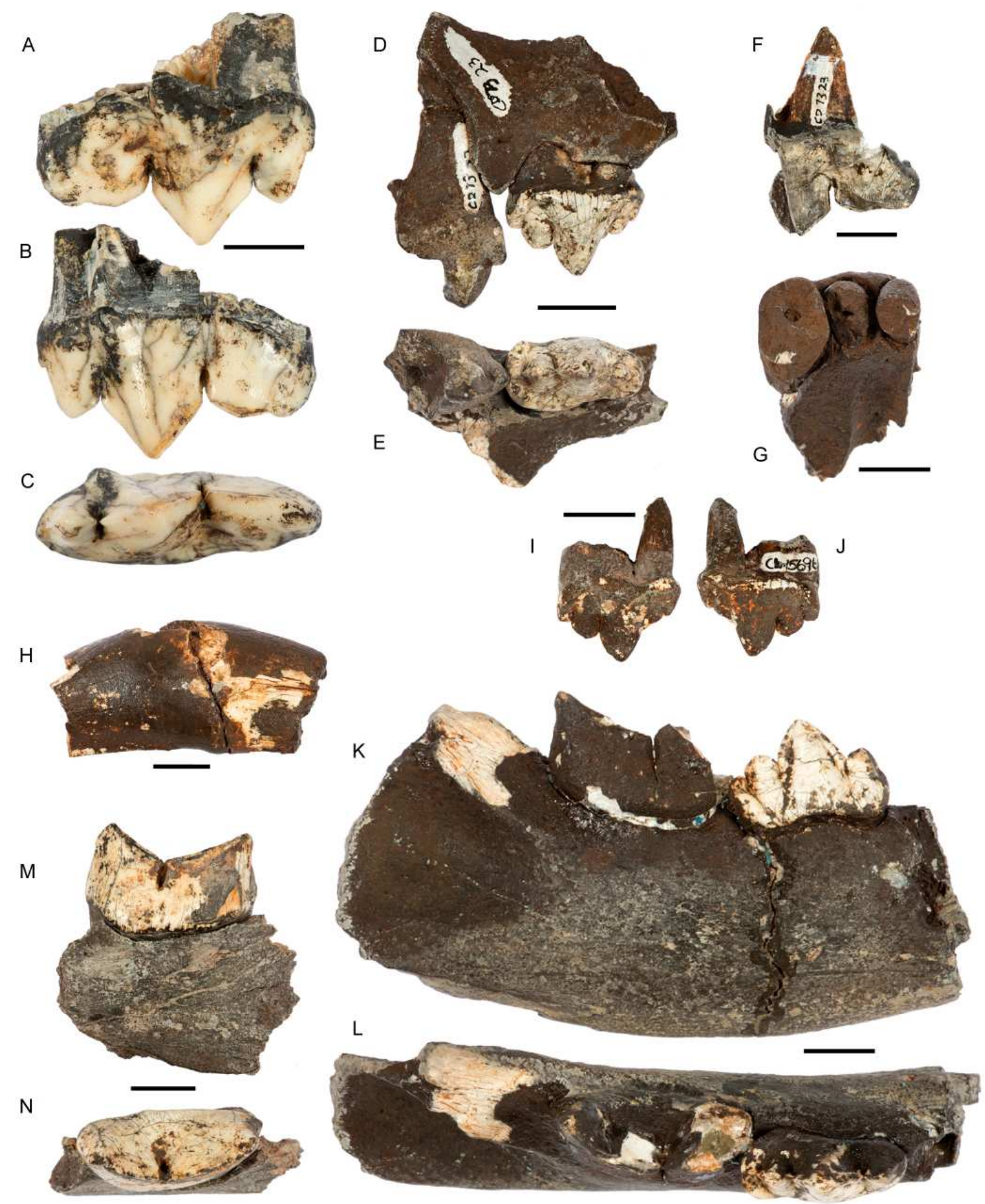

Figure 1. 


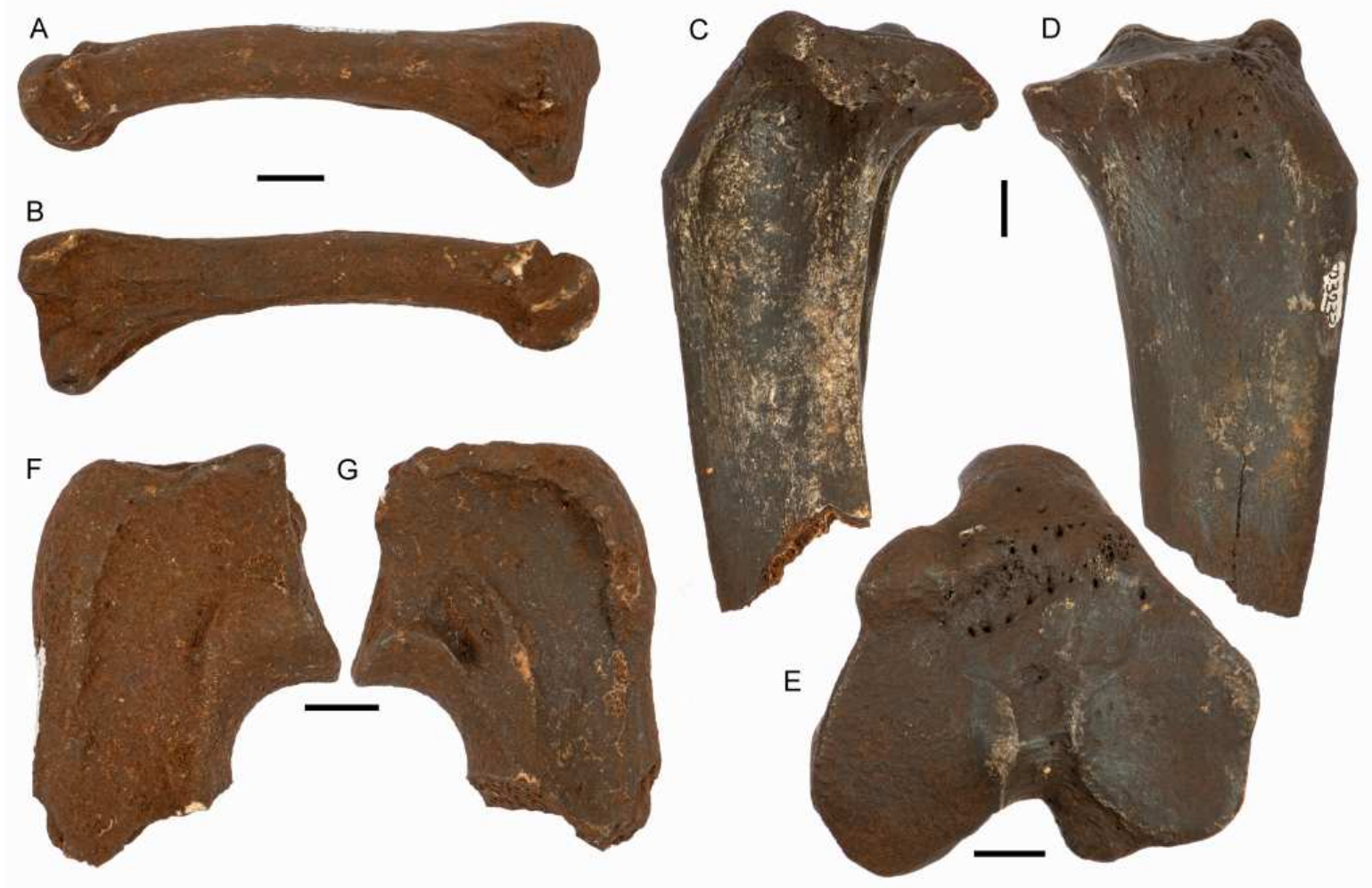

Figure 2. 


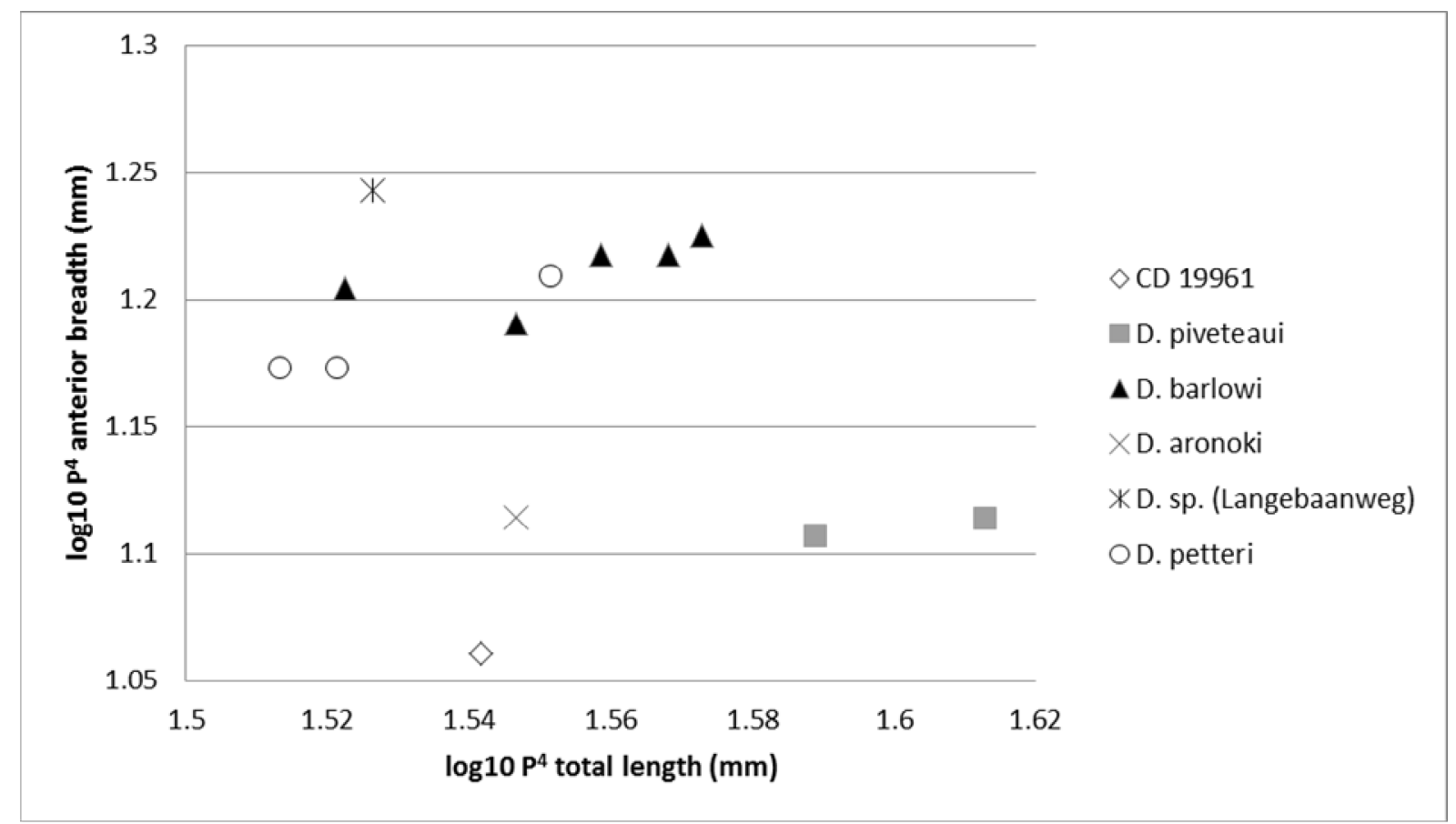

Figure 3. 


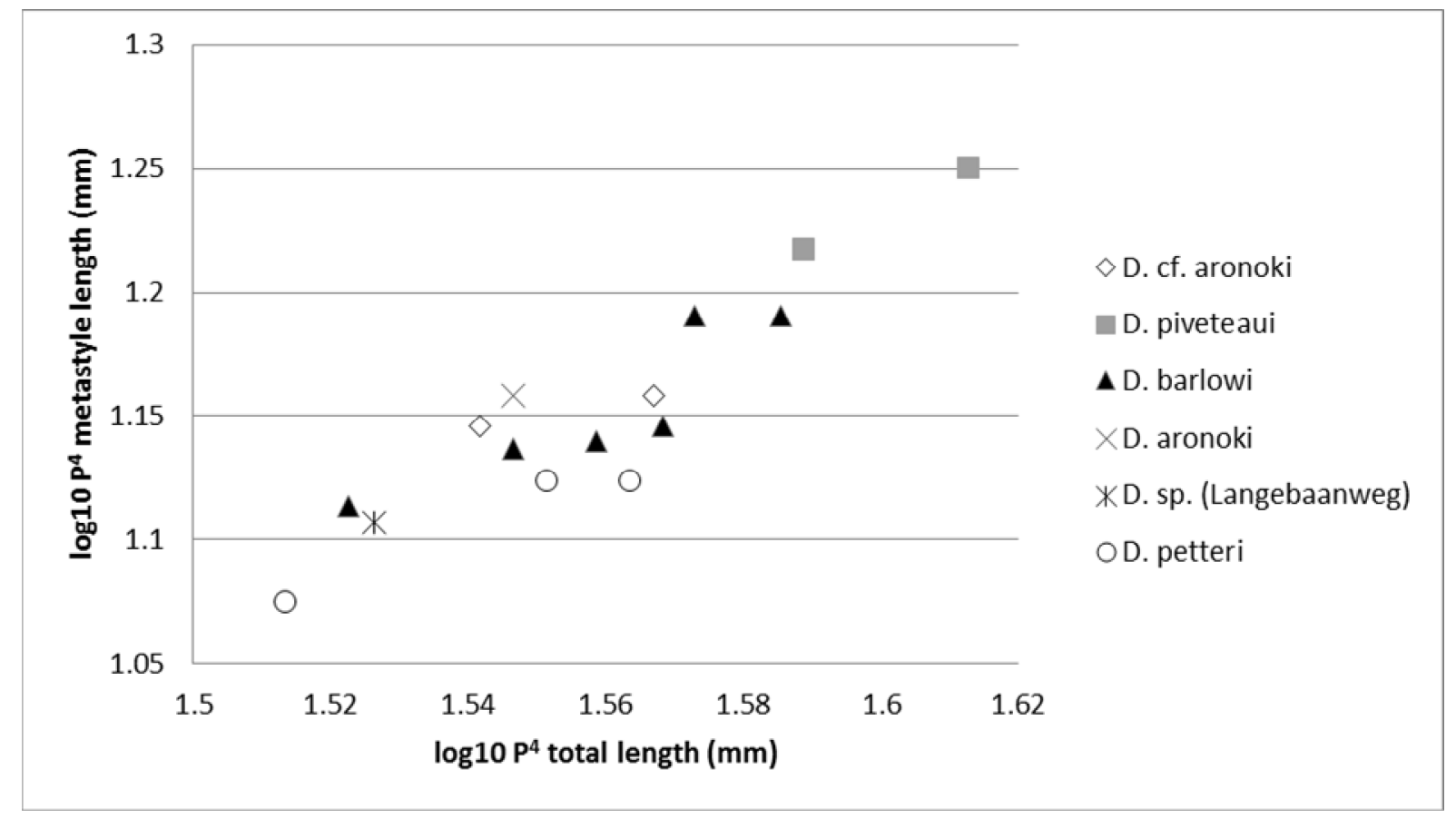




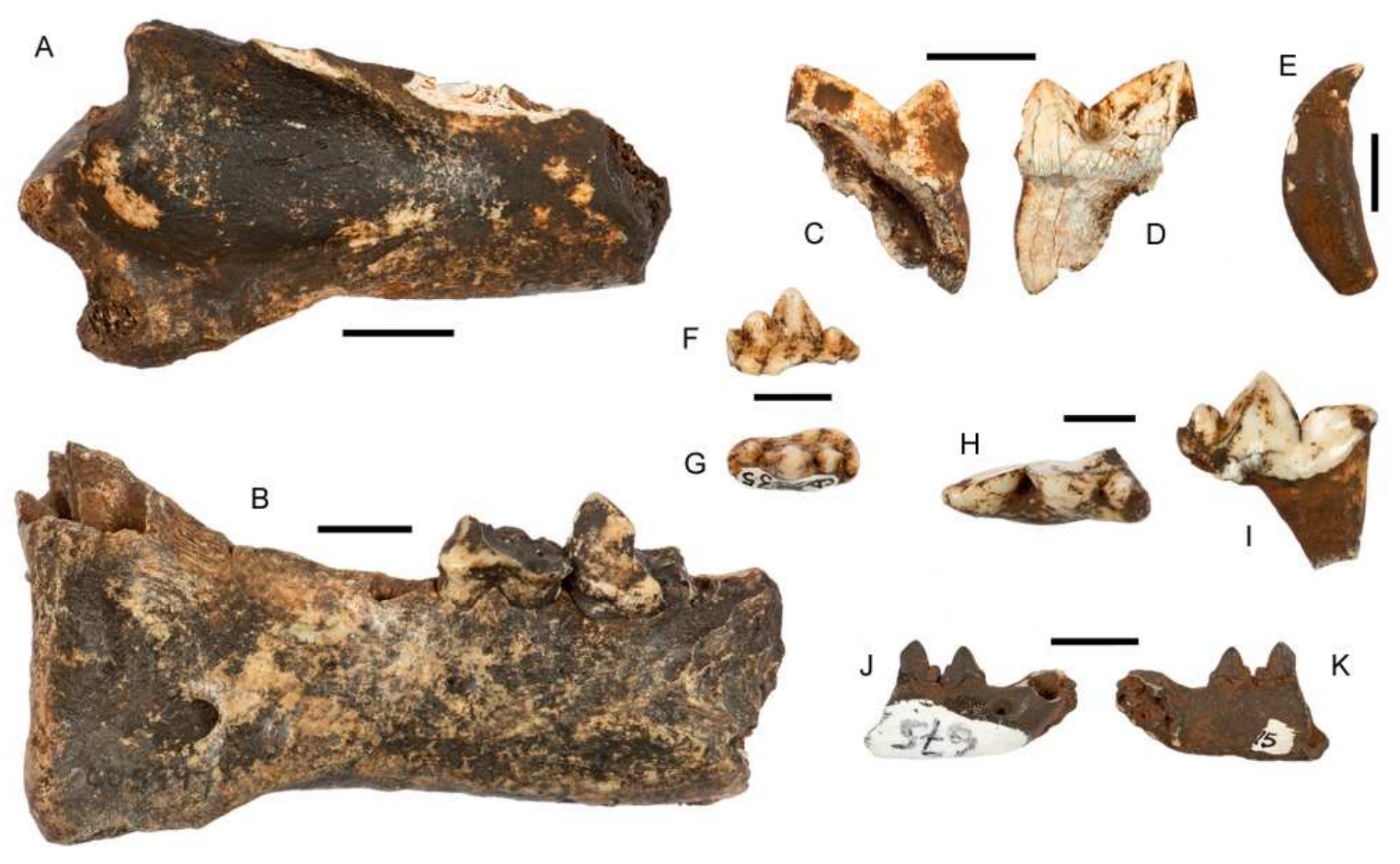

Figure 5. 


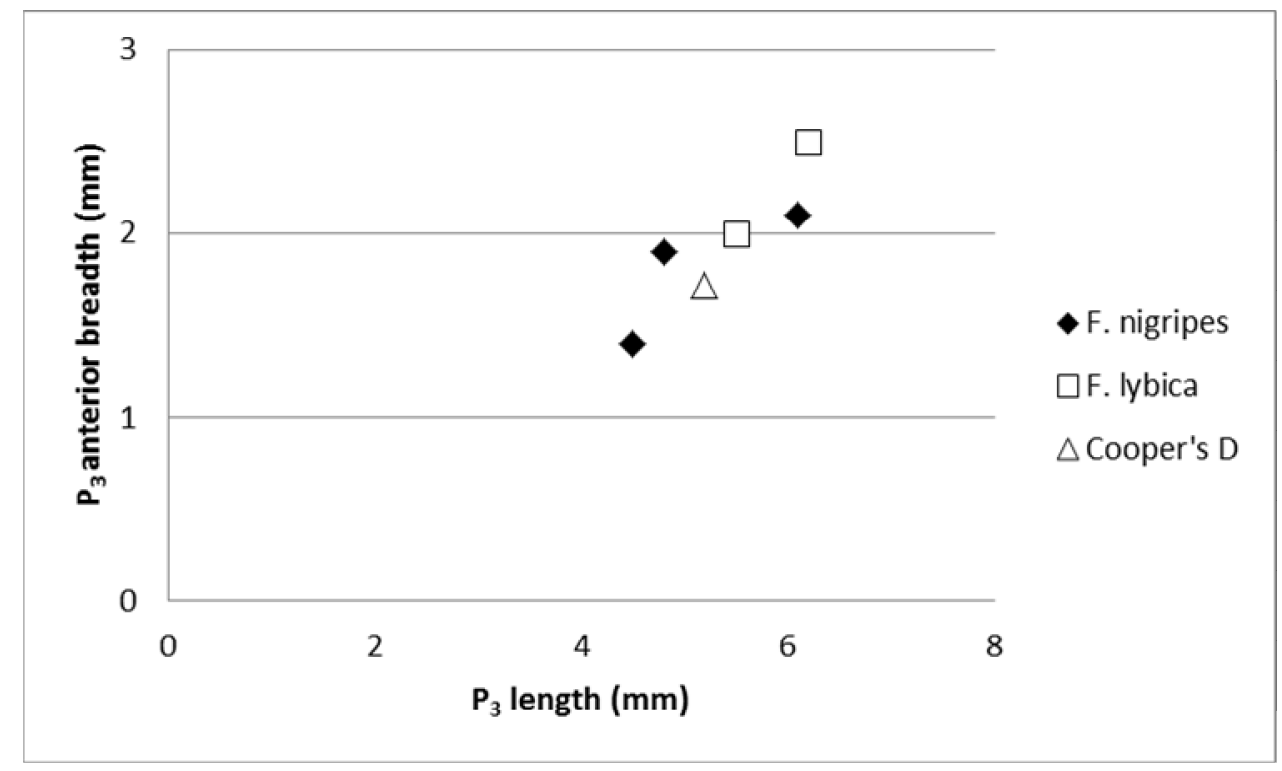

Figure 6. 
Table 1. Upper teeth and cranial measurements (in $\mathrm{mm}$ )

C

Specimen Side Taxon

number

CD 16769A

left

D. cf. aronoki

and $\mathrm{B}$

CD 19961

rig

CD 7323

right $\quad D$. cf. aronoki

CD 15696

CD 3835

CD3691

CD 3871

CD 691

CD 3258 right D. cf. aronoki

right Machairodontinae indet

both $\quad$ cf. P.pardus

left A.jubatus

left Felis s. lybica

right Felidae indet
$\mathbf{P}^{3}$

L B

L

B

Bant

$\mathbf{P}^{4}$

CB

$23.2 \quad 13.0$

$\begin{array}{ccccccc} & & & 34.8 & 11.7 & 12.8 & 14.2 \\ 17.2 & 8.2 & 6.9 & & & & >14.4 \\ \text { a17.4 } & \text { a8.4 } & \text { a6.2 } & & & & \\ \text { a17.2 } & \text { a8.2 } & & & & & \end{array}$

41.5

$\begin{array}{llll}\text { a27.7 } & 8.5 & 10.7 & 12.3\end{array}$


Table 2. Lower teeth and mandibular measurements (in mm)

$\mathbf{P} / 3 \quad \mathbf{P} / 4$

\begin{tabular}{|c|c|c|c|c|c|}
\hline Specimen & Side & taxon & $\mathbf{L}$ & B & Bant \\
\hline CD 19265 & left & \multicolumn{4}{|l|}{$\begin{array}{l}\text { D. cf. } \\
\text { aronoki }\end{array}$} \\
\hline CD 18836 & right & \multicolumn{4}{|l|}{$\begin{array}{l}\text { D. cf. } \\
\text { aronoki }\end{array}$} \\
\hline CD 1555 & right & \multicolumn{4}{|l|}{ cf. D. cf. } \\
\hline & & \multicolumn{4}{|l|}{ aronoki } \\
\hline CD 10452 & right & \multicolumn{4}{|l|}{$M$. } \\
\hline & & \multicolumn{4}{|l|}{ whitei } \\
\hline CD 1514 & left & \multicolumn{4}{|c|}{ Machairodontinae indet } \\
\hline CD 675 & right & Felis & 5.2 & 2.8 & 1.7 \\
\hline
\end{tabular}

P/4 M/1 cat

Bant L

L

26.9

$\begin{array}{lll}21.8 & 9.4 & 7.6\end{array}$

a26.7

$11.7 \quad 16.3$

a8.8

a28.2 a9

2.3
29.5

DEPTH B

$\begin{array}{lll}\mathbf{P} & \mathbf{P} / 4 \quad \text { Diastema }\end{array}$

13.8

$>11.5$

7.9
32.1

$4.8>5.1$ 
Table 3. Postcranial measurements (in mm).

\begin{tabular}{|c|c|c|c|c|c|c|c|}
\hline Specimen & Element & Side & Taxon & TL & $\begin{array}{l}\text { PWM- } \\
\text { L }\end{array}$ & PWA-P & DW Max \\
\hline CD $3712+$ & radius & right & cf. D. aronoki & & & & 37.7 \\
\hline \multicolumn{8}{|l|}{ CD5972 } \\
\hline CD 3277 & radius & & P. pardus & & $\mathrm{a} 22.8$ & 17.2 & \\
\hline CD 7369 & radius & left & P. pardus & & & & a29.6 \\
\hline \multirow[t]{2}{*}{ Specimen } & & Side & & TL & PW & ND & HD \\
\hline & & & & & Max & & \\
\hline CD 3233 & femur & right & D. cf. aronoki & & 67.2 & 23.8 & 29.3 \\
\hline CD 654 & femur & right & cf. D. aronoki & & & $\mathrm{a} 21$ & a28.1 \\
\hline Specimen & & Side & & TL & PW & DW max & DB Max. \\
\hline CD 3233 & tibia & left & D. cf. aronoki & & 52.9 & & \\
\hline CD 3881 & tibia & left & cf. D. aronoki & & & 38.2 & 23.7 \\
\hline \multirow[t]{2}{*}{ CD 1415} & tibia & right & cf. Megantereon & & & 34.7 & \\
\hline & & & whitei & & & & \\
\hline CD 18837 & tibia & right & Felidae indet & & & 38.6 & 24.5 \\
\hline Specimen & & Side & & TL & Neck & Head W & \\
\hline
\end{tabular}




\begin{tabular}{|c|c|c|c|c|c|c|c|}
\hline & & & & & $\mathbf{W}$ & & \\
\hline CD 3861 & astragalus & right & Felidae indet & & 17.5 & 22.5 & \\
\hline Specimen & & Side & & TL & TB & Min Shaft W & \\
\hline CD 1592 & calcaneum & left & Felidae indet & 43.7 & 15.9 & 7.5 & \\
\hline Specimen & & Side & taxon & TL & $\begin{array}{l}\text { PWM- } \\
\text { L }\end{array}$ & PWA-P & DW \\
\hline CD 717 & $\mathrm{MC} 2$ & left & $\begin{array}{l}\text { Machairdontinae } \\
\text { indet }\end{array}$ & & 12.2 & & \\
\hline CD 1500 & MC2 & right & $\begin{array}{l}\text { Machairdontinae } \\
\text { indet }\end{array}$ & & 12 & 15.9 & \\
\hline CD 13342 & $\mathrm{MC} 2$ & left & Felidae indet & & & 15.9 & \\
\hline CD 5703 & MC3 & left & $\begin{array}{l}\text { Machairdontinae } \\
\text { indet }\end{array}$ & & 14.4 & 13.2 & \\
\hline CD 1524 & MC3 & right & $\begin{array}{l}\text { Machairdontinae } \\
\text { indet }\end{array}$ & & 14.7 & 13.3 & \\
\hline CD 1944 & MC3 & left & Felidae indet & & 18.7 & 17.7 & \\
\hline CD 7354 & MC4 & right & $\begin{array}{l}\text { Machairdontinae } \\
\text { indet }\end{array}$ & & 11.4 & 13.6 & \\
\hline CD 3271 & MC5 & right & Machairdontinae & 47.4 & 8.1 & 13.6 & 11.3 \\
\hline
\end{tabular}




\begin{tabular}{|c|c|c|c|c|c|c|c|}
\hline \multirow{3}{*}{ CD 682} & \multirow{3}{*}{ MC5 } & \multirow{3}{*}{ left } & \multicolumn{5}{|l|}{ indet } \\
\hline & & & Machairdontinae & & 9.2 & 13.9 & \\
\hline & & & indet & & & & \\
\hline CD 3268 & MT2 & left & cf. M. whitei & & 9.1 & 17.9 & \\
\hline CD 19953 & MT3 & right & D. cf. aronoki & 85.9 & 19.2 & 23.4 & 19 \\
\hline CD 5957 & MT3 & right & P. pardus & a74.1 & 15 & 18.9 & 14.4 \\
\hline CD 1549 & MT3 & right & Felidae indet & a92 & a18.6 & & 17.12 \\
\hline CD 1522 & MT3 & right & Felidae indet & & 20 & & \\
\hline CD 670 & MT4 & right & cf. D. aronoki & & & & 15.52 \\
\hline CD 3836 & MT4 & left & P. pardus & & 7.8 & 13.4 & \\
\hline CD 8282 & MT5 & left & cf. P. leo & & & & 23.4 \\
\hline CD 3205 & MT5 & left & Felidae indet & & & & 13.1 \\
\hline
\end{tabular}


Table 4.

$\begin{array}{lrr}\text { Taxon } & \text { NISP } & \text { MNI } \\ \text { Dinofelis cf. aronoki. } & 11 & 2 \\ \text { Cf. Dinofelis aronoki } & 11 & \\ \text { Megantereon whitei } & 6 & 2 \\ \text { cf. Megantereon whitei } & 5 & \\ \text { Machairodontinae indet. } & 12 & \\ \text { Panthera leo } & 3 & 1 \\ \text { P. cf. leo } & 1 & \\ \text { Panthera pardus } & 8 & 1 \\ \text { cf. P. pardus } & 8 & \\ \text { Acinonyx jubatus } & 2 & 1 \\ \text { Caracal caracal } & 1 & 1 \\ \text { Felis sylvestris lybica } & 1 & 1 \\ \text { Felis sp. } & 2 & \\ \text { Felidae indet. (large) } & 31 & \\ \text { Felidae indet. (medium) } & 49 & \\ \text { Felidae indet. (small) } & 7 & \\ \text { Total } & 158 & 9\end{array}$

